\title{
Nomenclatural Synopsis of Cirsium Sect. Eriolepis (Asteraceae) in Italy
}

\author{
Emanuele Del Guacchio $^{1}$, Liliana Bernardo ${ }^{2} \mathbb{D}$, Paolo Caputo ${ }^{1,3}$, Francesca Carucci ${ }^{1}$, Gianniantonio Domina ${ }^{4} \mathbb{D}$ \\ and Duilio Iamonico ${ }^{5, *}$
}

\section{check for} updates

Citation: Del Guacchio, E.; Bernardo, L.; Caputo, P.; Carucci, F.; Domina, G.; Iamonico, D. Nomenclatural Synopsis of Cirsium Sect. Eriolepis (Asteraceae) in Italy. Plants 2021, 10, 223. https:// doi.org/10.3390/plants10020223

Received: 11 December 2020

Accepted: 20 January 2021

Published: 24 January 202

Publisher's Note: MDPI stays neutral with regard to jurisdictional claims in published maps and institutional affiliations.

Copyright: (c) 2021 by the authors. Licensee MDPI, Basel, Switzerland. This article is an open access article distributed under the terms and conditions of the Creative Commons Attribution (CC BY) license (https:/ / creativecommons.org/licenses/by/ $4.0 /)$.
1 Botanical Garden, University of Naples “Federico II", 80139 Naples, Italy; edelgua@email.it (E.D.G.); paolo.caputo@unina.it (P.C.); francesca.carucci@hotmail.it (F.C.)

2 Department of Biology, Ecology and Earth Sciences, University of Calabria, 87036 Arcavacata di Rende, CS, Italy; liliana.bernardo@unical.it

3 Department of Biology, University of Naples "Federico II", 80139 Naples, Italy

4 Department of Agricultural, Food and Forest Sciences, University of Palermo, 90128 Palermo, Italy; gianniantonio.domina@gmail.com

5 PDTA Department, University of Rome Sapienza, 00196 Rome, Italy

* Correspondence: d.iamonico@yahoo.it

\begin{abstract}
The names of the Italian taxa in Cirsium sect. Eriolepis are discussed. The accepted names are: Cirsium echinatum, C. eriophorum subsp. eriophorum, C. eriophorum subsp. spathulatum, C. ferox, C. italicum, C. lacaitae, C. lobelii, C. morisianum, C. scabrum, C. tenoreanum, C. vallis-demonii subsp. vallisdemonii, C. vallis-demonii subsp. calabrum comb. nov., and C. vulgare (= C. crinitum, C. sylvaticum). Four accepted names are typified by specimens preserved at FI (one lectotype), G (one lectotype and one neotype), $\mathrm{P}$ (one lectotype), and by illustrations (two lectotypes). Several other heterotypic synonyms of taxa described from Italy are discussed and six of them are typified. A new combination and status are proposed: C. vallis-demonii subsp. calabrum, based on C. eriophorum var. vallis-demonii f. calabrum.
\end{abstract}

Keywords: Carduinae; Carduus; Cnicus; Italian endemic plants; Epitrachys; Lacaita; L'Obel; Mediterranean flora; Petrak; Tenore; taxonomy; typification

\section{Introduction}

Cirsium Mill. (Asteraceae Bercht. \& J. Presl.: Cardueae Cass.) is a large genus comprising more than 450 species (as many as 491 according to POWO [1]), usually biennial or perennial spiny herbs, distributed in the northern hemisphere but also naturalized worldwide ([2-4]). Among the three sections currently recognized in Europe, sect. Eriolepis (Cass. in Cuvier) Dumort. (=Ci. sect. Epitrachys DC. ex Duby) is an extremely difficult group from the taxonomical point of view, and some taxa are only provisionally accepted ([5-7]. The members of this section are mostly biennial without vegetative multiplication, and they are characterized by pinnatifid and usually coriaceous leaves with segments divided into two divaricate basal lobes and with rigid setae (more properly, spines according to Keil [3]) on the upper surface of the blade, medium to large heads, middle involucral bracts with toothed margins, a narrow appendage abruptly contracted into one terminal and robust awn, corolla tube longer than limb (this latter more or less divided up to half), and pappus shorter to subequal than corolla (see e.g., $[5,7,8]$ ).

As a part of ongoing studies on the taxonomy of Cirsium sect. Eriolepis (see e.g., [9,10]) and on taxa endemic to central and southern Italy [11-17], we here present a nomenclatural contribution concerning the types of the names of the Italian taxa included in this section. To avoid confusions, the generic names Carduus, Cirsium, and Cnicus are abbreviated through the text as "Ca.", "Ci.", and "Cn." respectively.

According to Greuter [6], the following taxa belonging to $\mathrm{Ci}$. sect. Eriolepis occur in Italy: Ci. echinatum (Desf.) DC., Ci. eriophorum (L.) Scop., Ci. ferox (L.) DC., Ci. italicum DC., 
Ci. lacaitae Petr., Ci. lobelii Ten., Ci. morisianum Reich., Ci. scabrum (Poir.) Bonnet \& Baratte, Ci. spathulatum (Moretti) Gaud. (considered by $[18,19]$ as a subspecies of Ci. eriophorum), Ci. tenoreanum Petr., Ci. vallis-demonii Lojac., Ci. vulgare (Savi) Ten. subsp. vulgare, Ci. vulgare subsp. crinitum (Boiss. ex DC.) Arènes, and Ci. vulgare subsp. silvaticum (Tausch) Arènes. Four of these names (Ci. echinatum, Ci. eriophorum, Ci. scabrum, and Ci. vulgare) are combinations with basionyms in Carduus L.; two of them (Ci. ferox and Ci. spathulatum) are based on names in Cnicus L.

\section{Material and Methods}

This paper investigates the names in Cirsium sect. Eriolepis occurring in Italy and those published on Italian material, based on both analysis of the relevant literature (protologues included) and checking and/or examination of specimens kept at BOLO, BM, CAT, FI, G, H, K, LY, MS, NAP, OHN, P, PAD, PAL, PAV, PI, PRC, and RO [20]. The articles cited through the text belong to the Shenzen Code [21].

Within the group of our interest, numerous "microspecies" were published by Gandoger [22] under Eriolepis, together with new intended combinations, e.g., "Eriolepis apennina", "E. aprutia", "E. apula", "E. atrorubens", "E. brevispina", "E. brutia", "E. calabrica", "E. incerta", "E. insubrica", "E. lacerans", "E. lancifera", "E. leiantha", "E. leptacantha", "E. lobelii", "E. majellensis", "E. megachlamys", "E. messanensis", "E. misilmerensis", "E. nebrodensis", "E. nigricans", "E. parva", "E. recedens", "E. secundaria", “E. sicula”, “E. subpatens", "E. tenuis", and "E. tyrolensis". These names were generally not used later by Gandoger himself [23]. [24] attempted a synonimization of some of them. However, none of those names was validly published and they do not require any nomenclatural act [21]. Therefore, we excluded them from the present account.

\section{Typification of the Names and Taxonomic Treatment}

The taxonomic treatment generally follows [5], with the exception of Ci. vallis-demonii (which we split into two subspecies). Taxonomical notes are provided within each entry to justify our choice. In the following account, the accepted names are in alphabetical order; within each of them, the treated homotypic synonyms are listed in chronological order.

(1) Cirsium echinatum (Desf.) DC., Fl. Franc., ed. 3, 6: 465. 1815 三Carduus echinatus Desf., Fl. Atlant. 2: 247. 1799 (basion.) ECnicus echinatus Willd., Sp. Pl., ed. 4, 3(3): 1668. 1803.- - Lectotype (designated by Talavera \& Valdès [25] (p. 214)): Algeria. "Prope Mascar, in collibus arenosis", s.d., [R.] Desfontaines s.n. (G00446590 [digital image!]).-Figure 1.

Distribution-Species endemic to western Mediterranean (Tunisia, Algeria, Morocco, Spain, France and Sicily) [6].

Habitat-Dry, open habitats in the Mediterranean area, on sandy or claysh soils, often basic and nitrified, up to $2100 \mathrm{~m}$ a.s.1. [8,18,26].

Note-The combinations "Eriolepis echinata", "Eriolepis italica", and "Eriolepis ferox" are sometimes attributed to Cassini [27], who actually wrote in [28] (p. 470): "Le Cnicus ferox de Linné, [ ... ] le Cirsium echinatum de M. De Candolle (Flor. franc., Suppl.), et le Cirsium italicum du même botaniste (Cat. Hort. monsp.), appartiennent à notre genre ou sous-genre Eriolepis". Nevertheless, since Cassini (in [28]) did not definitively associate the epithets ferox, echinatum or italicum to Eriolepis, these combinations were not validly published (Art. 35.2). 


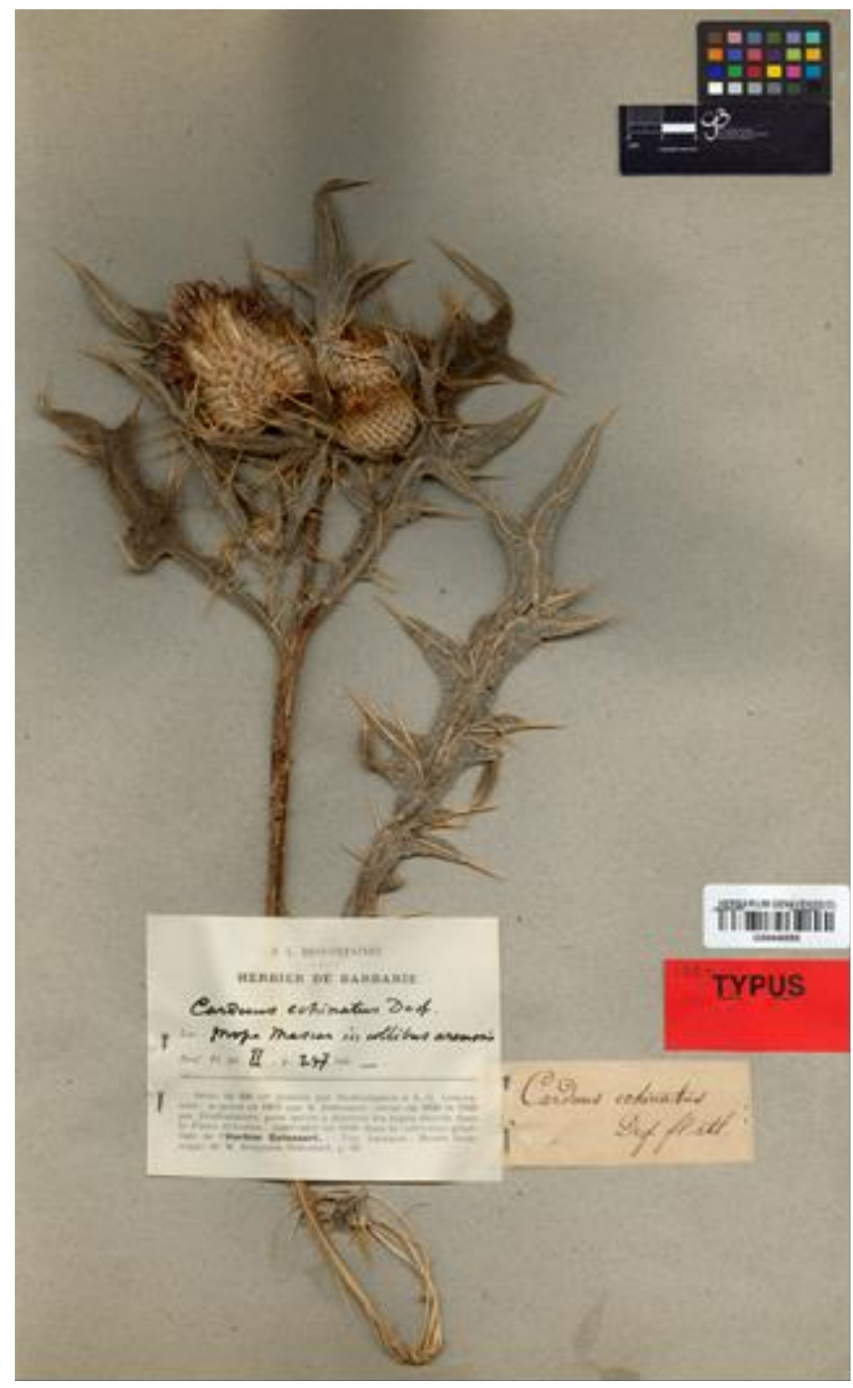

Figure 1. Lectotype of Ca. echinatus Desf. (G), by permission of the Curator.

(2) Cirsium eriophorum (L.) Scop., Fl. Carniol., ed. 2, 2: 130. $1771 \equiv$ Carduus eriophorus L. (basion.), Sp. Pl. 2: 893. 1753 三 Cnicus eriophorus (L.) Roth, Tent. Fl. Germ.: 345. 1788 E Eriolepis lanigera Cass. in Cuvier, Dict. Sci. Nat. 41: 331. 1826, nom. illeg. (Art. 11.4).-Lectotype (designated by Del Guacchio \& Iamonico [9] (p. 197)): Herb. Linnaeus, no. 966.32 (LINN [digital image!]).—http:/ / linnean-online.org/9831/.“Ci. eriophorum var. vulgare Naeg.", Syn. Fl. Germ. Helv., ed. 2, 3: 989. 1845, nom. inval. (Art. 26.2). "Ci. eriophorum subsp. eu-eriophorum var. genuinum Gillot", Rev. Bot. 12: 360. 1894, nom. inval. (Art. 24.3). "Ci. eriophorum subsp. vulgare Petr.”, Biblioth. Bot. 78: 15. 1912, nom. inval. (Art. 26.2).

Notes on Ci. eriophorum var. vulgare-The final epithet "vulgare" was associated by Naegelius [29] (p. 989) to "C. eriophorum Auct.". Among these authors, Naegelius [29] cited the Linnaean basionym under Carduus, and other combinations based on it. For this reason, the name clearly purports to indicate the taxon containing the type of the name of the next higher-ranked taxon, i.e., Ci. eriophorum. Therefore, in our opinion, Art. 26.2 must be applied and the name is to be regarded as invalidly published. Analogous reasoning can be applied for the name by Petrak ([24], p. 15), which cannot be formally based on that by Naegelius [29].

Distribution-Europe (from Spain to Romania, including Great Britain), and western Asia (Turkey); naturalized in Ireland [6,30,31]. 
Habitat-Mountain pastures, grasslands, wood margins and sometimes disturbed environments of temperate European climate, up to $2500 \mathrm{~m}$ a.s.l. (rarely below $600 \mathrm{~m}$ ), on rich soils over limestone and chalk $[8,30]$.

(3) Cirsium ferox (L.) DC. in Lamarck \& Candolle, Fl. Franç., ed. 3, 4: 120. $1805 \equiv$ Cnicus ferox L., Mant. Pl.: 109. 1767 三 Carthamus ferox (L.) Lam., Fl. Franç. (Lamarck) 2: 11. $1779 \equiv$ Ca. ferox (L.) Vill., Prosp. Hist. Pl. Dauphiné: $30.1779 \equiv$ Eriolepis ferox (L.) Fourr., Ann. Soc. Linn. Lyon, sér. 2, 17: 111. 1869 三 Cirsium eriophorum var. ferox (L.) Fiori, Fl. Italia [Fiori, Béguinot and Paoletti] 3: 367.1904 (sub var. "ferox (DC.)").—Lectotype (designated by Del Guacchio and Iamonico ([9], p. 198)): [illustration] Carduus lanceolatus ferocior in [32] (p. 58).-http:/ / bibdigital.rjb.csic.es/ing/Libro.php?Libro=4182\&Hojas.

Distribution-Species endemic to eastern Spain, southern France and North-western Italy $[6,8,19]$. Habitat:-Dry open habitats, pastures, roadsides, stony slopes in the Mediterranean area, up to $1500 \mathrm{~m}$ a.s.l. [8].

Note on Carthamus ferox-Lamarck [33] does not cite the basionym Cn. ferox L., but we think that in this case Art. 41.4 can be applied, cf. [34] (p. 120).

Note on Eriolepis ferox-For the presumed identical combination by Cassini (e.g., [27]), see the note to Ci. echinatum.

(4) Cirsium italicum DC., Cat. Pl. Horti Monsp.: 96. 1813 三 Carduus italicus (DC.) Savi, Bot. Etrusc. 3: 140. $1818 \equiv$ Cnicus italicus (DC.) Sebast. \& Mauri, Fl. Roman. Prodr.: 282. 1818. - Lectotype (designated here): Italy, "Entre Vallombrosa et Camaldoli", 18 August 1808, A. P. Candolle s.n. [(G-DC00486549 [digital image!]).-http:/ /www.villege.ch $/$ musinfo $/ \mathrm{bd} / \mathrm{cjb} / \mathrm{chg} /$ adetail.php?id=335990\&base=img\&lang=fr).

=Cnicus samniticus Ten.-Neotype (designated here): "In Samnio", s.d. [1825?], s.c., s.n. (BOLO [digital image!]).-Figure 2.

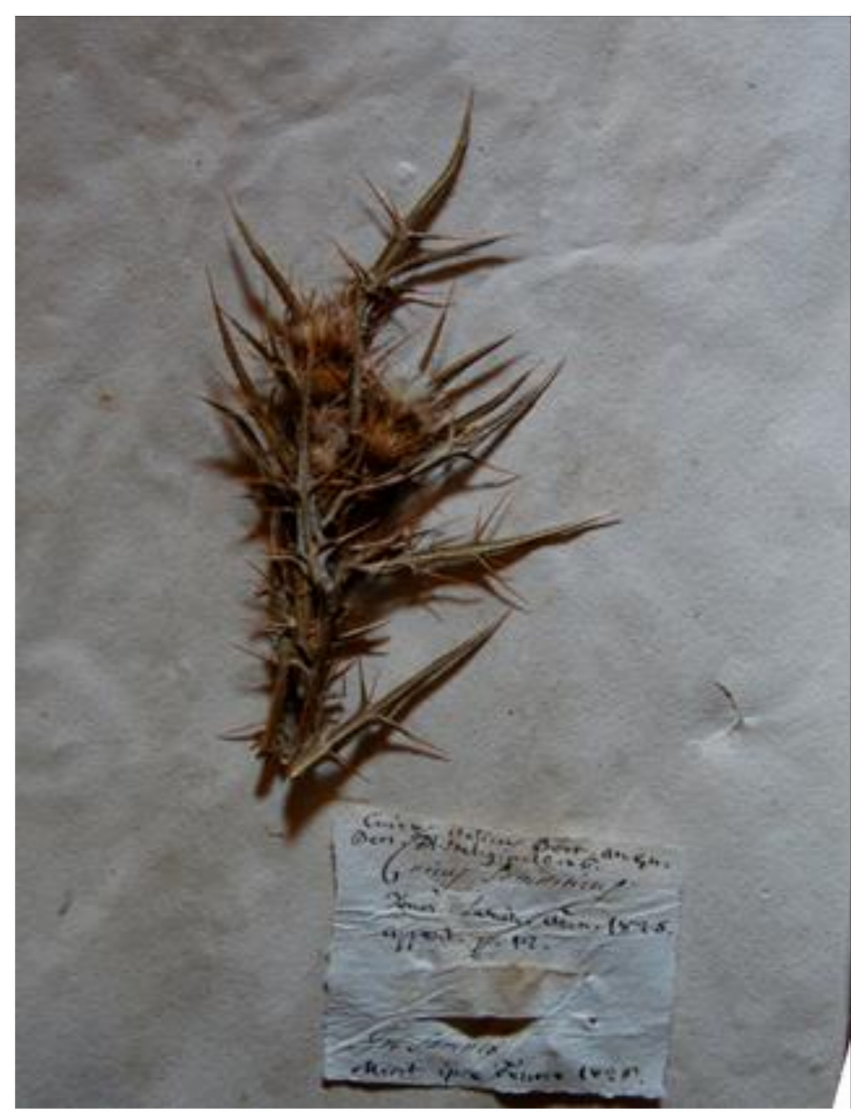

Figure 2. Neotype of Cn. samniticus Ten. (BOLO), by permission of the Curator.

Notes on Ci. italicum-Candolle [35] published Ci. italicum with a detailed Latin description, with the provenance ("In ruderatis Etruriae et agri Romani"; transl.: "In 
ruderal environments of Tuscany and the surroundings of Rome"), and a taxonomic note. Note that according to CHG [36] several specimens in G-DC from Tuscany (as that of Ci. italicum) were indicated as collected by Candolle himself, but we have not further proof of this statement. Candolle [35] cited also a synonym from L'Obel [37] (p. 15) ("Phoenix leo carduus ferox") and the illustrations of this plant by the same author ("p. 15 Figure 2"), by Dodoens [38] (p. 738), by Dalechamps [39] (p. 1489), and by Bauhin \& Cherler [32] (p. 92). All these images are original material for the name Ci. italicum; however, Dodoens [38] and Dalechamps [39] reproduced the same figure by L'Obel [40], while that by Bauhin \& Cherler [32] appears as a simplification of it [in fact, these authors report the description by L'Obel [40]. For simplicity's sake, we refer by "L'Obel (1581)" to the first edition of the illustrations excerpted from L'Obel [40], that is "traditionally, but erroneously attributed to Lobel" [41]. Similarly, we indicate by "L'Obel (1591)" the second edition of the same work. We also found one specimen at G-DC (G00486549, image available at http:/ / www. ville-ge.ch/musinfo/bd/cjb/chg/adetail.php?id=335990\&base=img\&lang=fr) that bears two flowered and fruiting stems (of possibly different individuals), collected by Candolle in Tuscany in 1808. The features of the exsiccatum match Candolle's diagnosis: leaves shortly decurrent (i.e., stems partly winged), pinnatifid, tomentose below and roughly setose above, heads almost sessile and surrounded by the upper leaves, involucral bracts glabrescent, appressed and ending into a spine. According to Davis \& Parris [42], this is the only member of the section showing vittae (in this case, a median rib on the bract). Besides, the label data fit the protologue information well. We designate this G-DC specimen as the lectotype of the name Ci. italicum. Our choice fully supports the current usage of the name, well deserved for a species endemic to North-Eastern Mediterranean: Corse, Italy (Sardinia and Sicily included), Malta, Albania, Greece and Turkey [6]. For a presumed combination "Ci. italicum (Savi) DC." [5], see [43]; for "Eriolepis italica Cass.", see our note to Ci. echinatum.

Notes on Cn. samniticus-Tenore [44] described Ci. samniticus in Latin and indicated the following provenance: "Habitat in montibus Samnii", i.e., "on the mounts of Sannio", an area roughly corresponding to southern Abruzzo, the modern Molise and North-eastern Campania regions in southern Italy. The protologue is included in the catalogue of the seeds collected in 1825 [44] and it could have been therefore published in 1825 or even in 1826. The only useful exsiccatum preserved in the Tenore Collection (NAP) bears a label by the author without the date of collection ("Cnicus samniticus $\backslash$ C. spinosissim. Florae nap. prodr. (in Samnio") and it is represented by an individual with flowers and ripe heads. The only other specimen that we were able to locate is preserved at BOLO: nowadays it is reduced to a single fragment of flowering scape, and collected "in Samnio". This specimen was labelled by Tenore himself as Cn. samniticus. In 1826 Tenore sent this specimen to Bertoloni, who added on the same label the references and the accepted name, i.e., Cn. italicus (cf. [45], p. 10). In our opinion it could be considered as original material for the name, but a definitive proof is lacking. In any case, it fully matches the original description [44]. We here prudentially propose it as neotype according to the Art. 9.7. Nowadays, Ci. samniticus is regarded a heterotypic synonym of Ci. italicum [18], and we agree by examining the relevant specimens (stems partly winged; small and glabrescent heads crowded upwards and exceeded by the apical leaves; involucral bracts vittate with patent spines).

Distribution-Endemic to North-Eastern Mediterranean Basin, from France (Corse) to Asiatic Turkey; naturalized in Germany [6].

Habitat_-Arid meadows, shrublands, uncultivated fields, roadsides, up to $1100 \mathrm{~m}$ a.s.l. [18].

(5) Cirsium lacaitae Petr., Österr. Bot. Z. 64: 456. 1914 三 Cirsium stabianum Lacaita, Nuovo Giorn. Bot. Ital. n.s. 25: 120. 1918, nom. illeg. (Art. 52).—Lectotype (designated by Del Guacchio et al. [10]): Italy "Scala (Salerno) in Monte Canalitto, solo pomiceo, c. 1260 m", 22 September 1912, C. Lacaita 14574, rev.. Petrak 1913 (BM001043042 [digital image!]). https://data.nhm.ac.uk/dataset/collection-specimens/resource/05ff2255-c3 8a-40c9-b657-4ccb55ab2feb/record/1971435. 
Note on Ci. stabianum-This superfluous name is homotypic with Ci. lacaitae (Art. 7.5).

Distribution-This is the rarest representative of the section in Italy, restricted to Campania (southern Italy); known for the Peninsula of Sorrento [46], where it had been re-discovered, it also occurs on Picentini Massif [47]. In addition, some reports of Ci. morisianum from the same region are probably to be referred to Ci. lacaitae as well (Del Guacchio, pers. obs.). In fact, in agreement with Lacaita [46], we think that Ci. lacaitae is mostly related to Ci. morisianum, and it could be a southern vicariant of it; however, no intermediate populations have been yet described.

Habitat-Beech and chestnut woods, clearings, usually on rich and mature soils, at about 600-1300 $\mathrm{m}$ a.s.l. [47].

(6) Cirsium lobelii Ten., Index Sem. Hort. Bot. Neapol. 1830: 16. $1830 \equiv$ Ci. eriophorum subsp. lobelii Rouy, Bull. Soc. Bot. France 51: 428. $1904 \equiv$ Ci. eriophorum var. lobelii (Ten.) Fiori, Fl. Italia [Fiori, Béguinot \& Paoletti] 3: 367. 1904.-Lectotype (designated here): [illustration] "Phoenix. Leo. Carduus ferox" in L'Obel [40] (p. 15).- http: / /bibdigital.rjb.csic.es/ing/Libro.php?Libro=4362\&Hojas.—Epitype (designated here): Italy, Abruzzo, Monte Morrone, August 1914, D. Profeta s.n. (P04277119 [Digital image!]). —http://mediaphoto.mnhn.fr/media/1441358086652IKEzLI1D5aQmeuQZ.

=Cirsium morisianum var. aprutianum Petr, Biblioth. Bot. 78: 15. 1912.-Lectotype (designated here): Italy, Abruzzi, "in pascuis saxosis montis Morrone et Majella in Valle Cupa et al.la Rapina", "sol. cal.—m. 2000-400" [on calcareous soil at 2000-2400 m a.s.l.], August 1905, G. Rigo (P, P04316688 [digital image!], sub "Cirsium Moritzianum Reich." [sic!]).-http:/ / mediaphoto.mnhn.fr/media/14413587569952aN3OdAPGgtS3EPg.

- Cirsium ferox L. var. lobelii sensu DC.

"Ci. eriophorum L. subsp. odontolepis (Boiss. ex DC.) Rouy var. aprutianum Rouy", Bull. Soc. Bot. France 51: 428. 1904, nom. inval. (Art. 38.2 Ex.1).

Notes on Ci. lobelii-The protologue of this name [48], dedicated to the famed Flemish botanist Mathias de L'Obel (1538-1616), includes a Latin description and the same polynomial by L'Obel ([40], p. 15) himself, already cited by Candolle [35] for Ci. italicum. According to our research, the personal copy of Tenore was a second edition of the work (L. Paino, pers. comm.), and also the other two copies known in Naples (one lost) were 1591 editions. Indeed, Tenore [48] listed the same illustrations cited by Candolle, i.e., those by Dodoens ([38], p. 738), ("788" in the Tenore protologue), by Dalechamps ([39], p. 1489), and by Bauhin and Cherler ([32], p. 92). In fact, according to Tenore [48], all these illustrations (which are original material) could be referred to his Ci. lobelii, rather than to Ci. italicum. This statement is reliable, in our opinion (cf. also [46]). In fact, even if somewhat compatible with the illustration by L'Obel [37,40], Ci. italicum has semi-winged stems, what is not clearly shown in the figure. In the protologue [48], a diagnostic comparison with Ci. ciliatum (Murr.) Moench and Ci. italicum was also provided. Tenore [48] also proposed two unnamed varieties: "var. A" ("Caulis 1-2 pedalis apice tantum ramosus, flores 6-8 lin. diametri"; transl.: "Stem 30-60 cm tall, branched only at the apex, with heads $12-16 \mathrm{~mm}$ in diameter"), which should be intended as the typical one, and "var. B" ("Planta ramosissima omnibus partibus duplo major, spinis robustissimis horrida"; transl. "A very branched plant, twice larger in every part than the former variety, with very robust spines"). Lacking the varietal epithet, these two varieties were not validly published (Art. 32.1, Note 1). On the basis of the diagnoses, they appear as compatible with the taxa currently called C. lobelii and C. lacaitae, respectively, as indicated by Lacaita [46]. This latter author suggested that the original description of $\mathrm{Ci}$. lobelii was drawn up by field samples, not preserved by Tenore afterwards. His very detailed account of all the specimens preserved at NAP and those sent by Tenore to other botanists (all gathered after the protologue's publication), and of the numerous citations (or illustrations) occurring in the Tenore's works, definitively clarifies that Tenore used the name Ci. lobelii for different taxa. Actually, we have not been able to trace any specimen identifiable as original material either in the Tenore's Collection at NAP, or at FI, G, and RO. However, a specimen at BOLO, collected on the mounts of Sannio, was sent by Tenore himself to Bertoloni in 1830 under the name Ci. lobelii, and filed 
as Cn. eriophorum var. " $\beta$ " by Bertoloni [43] (p. 26). A further specimen is at $K$ (K000778040, http:/ / apps.kew.org/herbcat/getImage.do?imageBarcode=K000778040). It was collected in Abruzzo, sent by Tenore to J. Gay on May 1830, and bears a label handwritten by Tenore himself. The sending dates strongly suggest that these specimens may be original material. The plants on both the sheets at BOLO and $\mathrm{K}$ are not the ones currently named Ci. lobelii, but actually Ci. tenoreanum. In fact, the heads are less wide than $30 \mathrm{~mm}$, the involucral bracts are patent with a rhombic, typically purplish appendage, the tube is more or less equalling the limb. As a consequence, we designate the image by L'Obel [40] as the lectotype of the name Ci. lobelii to preserve the current use. Fortunately, this illustration matches the Tenore's diagnosis, and also corresponds to the current concept of the related taxon (whose circumscription is largely based on the Lacaita's concept). The taxon is endemic to Apennines (Italy) [5,18]. However, since the illustration is not univocally identifiable with C. lobelii [46], an epitype is to be chosen (Art. 9.8). We choose a specimen at P (04277119, http:/ / mediaphoto.mnhn.fr/media/1441358086652IKEzLI1D5aQmeuQZ) collected in "Abruzzi" (locus classicus) and originated from the herbarium of Lacaita, who first limited the modern application of the name and reported the gathering of the epitype, with a photograph [46]) (p. 121, Plate II).

Notes on Ci. ferox var. lobelii-The Tenore name Ci. lobelii was used by Candolle [49] to propose the combination at the varietal rank under Ci. ferox. However, on the basis of Candolle's description and the examination of a specimen sent to him by Tenore ("in Aprutio e Lucania ... 1833", G-DC, code 00486593!), we deduce that, by his combination, Candolle actually indeed indicated C. tenoreanum (see also [46]). Nevertheless, the combination by Candolle has the same nomenclatural type of $\mathrm{Ci}$. lobelii, and therefore it must be referred to the same taxon (Art. 48.1, Note 1). However, as first observed by Lacaita [46], it is rather surprising that Candolle [49], in the same work, identified two specimens of the same species with two different taxa, i.e., Ci. ferox var. lobelii and Ci. eriophorum var. spurium.

Notes on Ci. eriophorum subsp. lobelii-Rouy [50] (p. 428) proposed this combination applying Tenore's basionym Ci. lobelii to Ci. tenoreanum (as most authors did) and erroneously indicating its presence also in Greece. Nevertheless, Ci. eriophorum subsp. lobelii is homotypic with Ci. lobelii (Art. 7.3).

Notes on Ci. eriophorum subsp. odontolepis var. aprutianum-By this name, Rouy [50] intended to indicate the plant nowadays named Ci. lobelii, as Lacaita [46] clarified on the basis of a specimen kept in the Gussone's collection (NAP) and revised by Rouy. Unfortunately, this specimen cannot be anymore traced at NAP (R. Vallariello, in litt.). However, since the name was published without a diagnosis or description, or a reference to a former one ("C. Lobelii bot. ital. nonnull., non Ten."), it is a nomen nudum and therefore invalid (Art. 38.2, Ex.1).

Notes on Ci. morisianum var. aprutianum-Petrak [24], when intended to transfer the invalid varietal name of Rouy [50] under Ci. morisianum, actually described a new variety (Art. 12). He provided a detailed description and a diagnosis (in Latin) to distinguish the variety from the typical $\mathrm{Ci}$. morisianum, a rich list of syntypes, the native range (unfortunately confusing Calabria with Abruzzi), and an original illustration of the involucral bracts. Besides, he added some accurate notes in German language. Among the numerous syntypes, Petrak [24] cited no. 4142 of the series "Herbarium normale", collected by Rigo in 1898 ([51], p. 42), under "Cirsium Boujarti"), and other material gathered by Rigo himself (in addition to the herbaria cited by Petrak, the syntypes are nowadays also preserved-for example-at FI, NAP, P and US). We propose a syntype gathered by Rigo in 1905, derived from the Herbarium of L. Giraudias as the lectotype. It was reported by Petrak [24] with minor inaccuracies and revised by him in 1910. The specimen is complete of basal leaves and of a stem with two heads, one flowered and the other one in fruit: it represents without doubt the typical $\mathrm{Ci}$. lobelii as circumscribed by modern authors.

Distribution-Species endemic to central Italy, southward to Campania [19], where, however, its distribution would require verification (Del Guacchio, pers. obs.). For example, it does not occur in the Peninsula of Sorrento [46,52]), despite the statement by Pignatti [18]. 
Habitat-Mountain pastures, rocky slopes, screes, on limestones, from about $1000 \mathrm{~m}$ to $2000 \mathrm{~m}$ a.s.1. [18].

(7) Cirsium morisianum Rchb., Icon. Fl. Germ. Helv. 15: 59. 1853 三 Cirsium eriophorum var. morisianum (Rchb.f.) Fiori, Fl. Italia [Fiori, Béguinot and Paoletti] 3: 367. $1904 \equiv$ Ci. eriophorum subsp. morisianum (Rchb.f.) Briq. and Cavill. in Burnat Fl. Alp. Marit. 7: 19. 1931.-Lectotype (designated by Lacaita ([46], p. 131)): France, "In collibus aridissimis supra Tenda Carlinum versus inter Genistam candicantem", 23 July 1843, H. G. Reichenbach s.n. (W).

Notes on Ci. morisianum-The protologue of C. morisianum [53] is composed of a Latin diagnosis, a description, and the details of the gathering on the hills above the town of Tenda, in South-eastern France at the border with Italy (" [ . . ] in collibus aridissimis supra Tenda Carlinum versus [ ... ] 23. Jul. 1843 [ . . ] Rchb. fil.!"); an illustration (“Tab[ula] 94. DCCCXXV") [53] (pl. 94) is also provided and it is part of the original material. Lacaita [46], incidentally indicated as "autotipo" the specimen by Reichenbach filius examined by Petrak ([24], p. 45) and preserved at W at that time ("H. N. W.", according to the legend in ([24], p. 4)). In his works, Lacaita [46] often employed the term "autotipo", which we can translate as "obvious lectotype". Therefore, the designation by Lacaita [46] is valid and must be retained (Art. 7.11). However, note that our researches at $W$ were useless, and it cannot be excluded that a new lectotype, possibily the illustration, should be designated in the future according to Art. 9.11.

Distribution-Species endemic to France (Maritime Alps) and northern and central Italy $[6,19]$.

Habitat-Mountain pastures, rocky slopes, shrublands, pathways from $500 \mathrm{~m}$ to $1800 \mathrm{~m}$ a.s.l. [18].

(8) Cirsium scabrum (Poir.) Bonnet \& Baratte, Expl. Sci. Tunisie, Cat. Pl.: 238. $1896 \equiv$ Carduus scaber Poir. (basion.), Voy. Barbarie 2: 231. 1789 三 Ca. giganteus Desf., Fl. Atlant. 2: 245. 1799, nom. illeg. (Art. 52.2) 三 Cirsium giganteum Spreng., Syst. Veg. 3: 375. 1826, nom. ill. (Art. 58.1, Note 1) 三 Cnicus giganteus Willd., Sp. Pl., ed. 4, 3(3): 1671. 1803, nom. illeg. (Art. 58.1, Note 1).-Lectotype (designated here): "Numidia", s.d., Poiret s.n. (P02837964 [digital image!], sub Ca. scaber).—https:/ / science.mnhn.fr/institution/mnhn/collection/ $\mathrm{p} /$ item $/ \mathrm{p} 02837964$ ? listIndex $=8$ \&listCount $=29$.

$=\quad$ Carduus gigas Ucria, Nuova Racc. Opusc. Aut. Sicil. 6: 255. 1793.-Lectotype (designated here): [illustration] "Carduus gigas acanthoides tomentosus, pycnopolysphaerocephalus" in Cupani [54] (Plate 170).-Figure 3.

= Cirsium elatum Tod., Index Seminum [Panormitani]: 25. 1858, nom. illeg. (Art. 53.1), non Ci. elatum Sauter, Flora 28: 130. 1845.-Lectotype (designated here): Italy, Sicily, Rifiesi [=Rifesi], fine di giugno [18] 52, [A.] Todaro s.n. (PAL, no. 10462!, sub Cnicus elatus).—http:/ /147.163.105.223/zoomify / view_img.asp?ic=10462.

= Cirsium giganteum var. macrocephalum Lojac., Fl. Sicul. 2(1): 160. 1903.-Lectotype (designated by Aghababyan et al. [55] (p. 522)): Italy, Sicily,] Santa Cristina, s.d., [A.] Todaro s.n. (PAL, no. 10357!).—http:/ /147.163.105.223/zoomify/view_img.asp?ic=10357).

$=\quad$ Cirsium gigas var. eriophorum Lojac., Fl. Sicul. 2(1): 160. 1903.-Lectotype (designated by Aghababyan et al. ([55], p. 522)): Italy, Sicily, s.d., [A. Todaro] s.n. (PAL, no. 10460!)._-Image of the lectotype available at http:/ / 147.163.105.223/zoomify/view_ img.asp?ic $=10460$. 


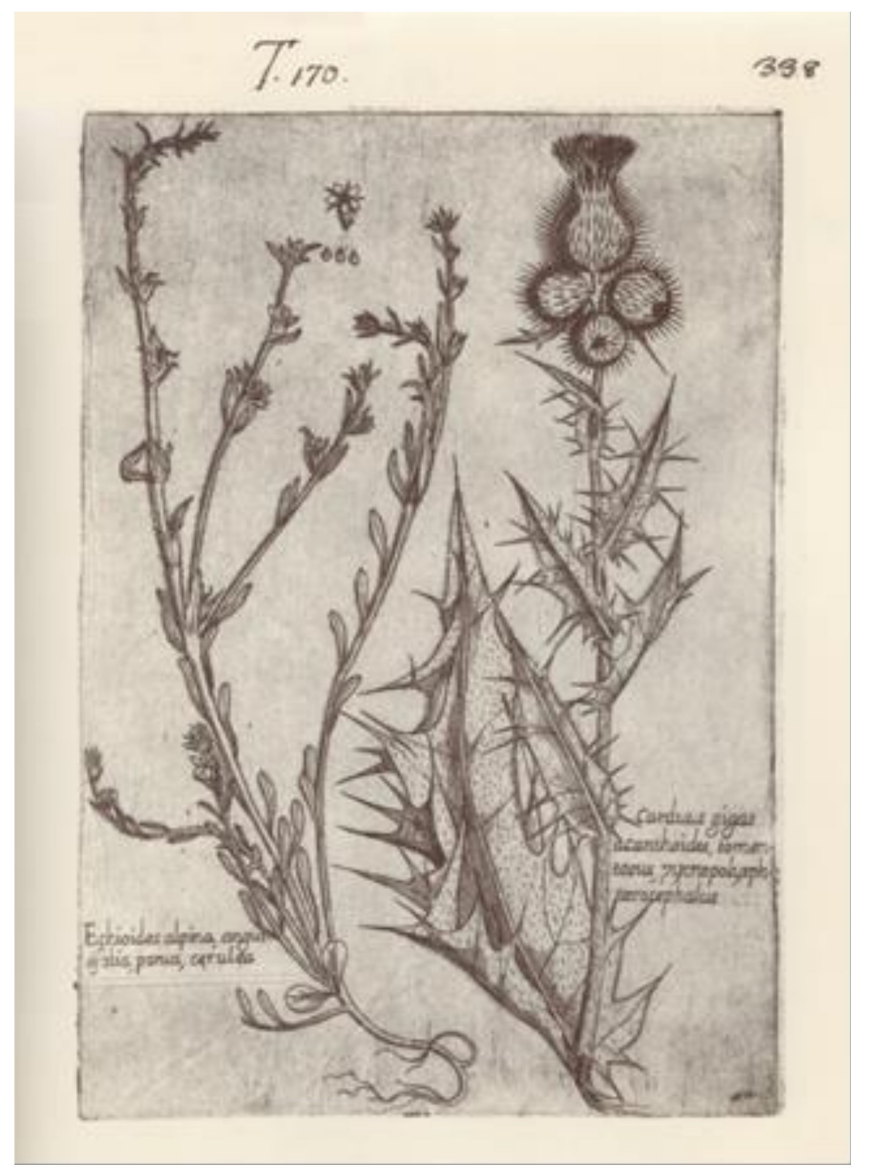

Figure 3. Lectotype of Ca. gigas Ucria (from the Panphyton siculum, plate 170, figure on the right side).

Notes on Ca. scaber-Poiret [56] validly published this name by a Latin diagnosis ("Foliis amplexicaulibus lanceolatis dentato-spinosis supra scabris et viridibus; subtus tomentoso-albis, calyce inermi"; transl.: "[A Carduus] with leaves embracing, lanceolate, with spiny teeth, bristly and green above, lanate an whitish below, with unarmed involucres"), a description in French, and a taxonomic note. In particular, he hypothesized that the same plant could have been indicated by Tournefort by the polynomial "Cirsium orientale, cardui lanceolati folio flore purpurascente". Finally, he indicated as habitat the stony and dry hills inhabited by the tribe of Nadis, probably corresponding to the area between North Tunisia and Algeria.

Only a single, relevant specimen is kept at P (F. Jabbour, in litt.). It originated from Poiret's Herbarium and was later included in the collection of Moquin-Tandon. Poiret handwrote on the label "Carduus scaber (nobis)" and below (possibly later) "Card. Giganteus Desf. Atl.". A different hand added, among other notes: "herb. Poiret ex Numidia" (a Latin term indicating the North-western Mediterranean Africa). Further pertinent material is lacking in the herbaria linked to Poiret: i.e., BR (F. Verloove, in litt.), FI (C. Nepi, in litt.), H (H. Väre, in litt.), UPS (M. Hjertson, in litt.) [57].

The name is the basionym for the accepted combination in Cirsium: our designation fully supports the current use of the name, on account of the large and not deeply divided leaves, heads in panicle more crowded upwards, the entire involucral bracts, which are appressed and tapering into an erect and short spine [5,8,18,26].

Notes on Ca. gigas-The protologue of $\mathrm{Ca}$. gigas consisted of a short diagnosis ("CARDUUS Gigas foliis sinuato-spinosis, ramis floriferis brevibus"; transl.: "A Ca. very tall, with leaves sinuate-spiny, and heads brought by short branches) [58]. The author also reported a synonym from Francesco Cupani's Panphyton Siculum ("Cup. Pamph.") [54]. This work is actually "a collection of engravings of plants, animals and minerals", remained uncomplete because of the premature death of the author [59]. However, much of his engravings 
(among which that of our interest) were published in 1713 (see Costa et al. [59]). The species was already reported by Cupani ([60], p. 37) with a slightly different polynomial ("Carduus gygas, pyramidalis, Acanthi foliis, tumentosis, pycnopolysphaerocephalus, flore albo"), noting also a purple-flowered variant. As the reference to Panphyton siculum by Ucria [58] is actually the citation of an illustration. This latter represents an element of the original material, probably the only one in existence. In fact, no specimen of Ucria's was traced. The engraving of our interest represents the flowering stem of a thistle. Currently, Ca. gigas is regarded as a synonym of $\mathrm{C}$. scabrum, and the above-said engraving (i.e., the proposed lectotype) is compatible with this identification: stem robust and rather unwinged, heads ovoid (only one at anthesis) in a racemiform array with short lateral branches, cauline leaves more or less plain, setose (or tomentose) on both the surfaces, lanceolate and acute, with spiny margins.

Notes on Ca. giganteus-Desfontaines [61] published the name Ca. giganteus by a diagnosis ("CARDUUS caule lanato; foliis cordatis, amplexicaulibus, sublobatis, superne hispidis subtus tomentosis, incanis, pedunculis uni ad trifloris"; transl.: "A Carduus with lanose stem; with leaves cordate, embrassing, sublobate, bristly above, covered by whitish tomentum below, with peduncles bearing up to three heads"), and a detailed Latin description. He also indicated the provenance ("Habitat in sepibus Algeriae"; transl.: "In the hedges of Algeria") and provided an illustration [61] (plate 221), explicitly indicated in the protologue, which is part of the original material ("Tab[ula] 221", https:/ / www.biodiversitylibrary.org/item/7542\#page/672/mode/1up). However, since Desfontaines [61] cited the validly published Ca. scaber as a synonym, Ca. giganteus is superfluous and illegitimate (Art. 52.2), and the type of this latter name is that of Ca. scaber (Art. 7.5). Analogously, the intended new combinations $\mathrm{Ci}$. giganteum and $\mathrm{Cn}$. giganteus are illegitimate as well (Art. 58.1).

Notes on Ci. elatum-Todaro [62] published this name in Latin with description, diagnosis, habitat and indication of the loci classici, all in southern Sicily: "Monti di Rifesi, vicino Palazzo Adriano, fiume della Verdura sotto Ribera". He also pointed out that he had preserved the plant in the Herbarium Panormitanum under the name Cnicus elatus. We located a pertinent specimen at PAL (no. 10462, http:/ /147.163.105.223/herbarium_vdetails_en2 .asp?idmode=simple\&id=22454). It includes a basal leaf and a cyme of mature heads, and was collected by Todaro himself at Ripesi, one of the loci classici, before the publication of the protologue. It is included in the fascicle of Cn. elatus, and, on the basis of the reference in the protologue, it could be even regarded as a syntype. Its examination fully supports the synonymization of Ci. elatum Tod. with Ci. scabrum (see Fiori [52]). Nevertheless, the name is illegitimate under Art. 53.1, because of the existence of the prior Ci. elatum by Sauter [63] (p. 130).

Distribution-A South-Western Mediterranean taxon, which indicates a species endemic to Western Mediterranean, occurring in Italy (Sardinia and Sicily included), France (Corse), Spain, Morocco, Algeria and Tunisia; locally adventitious in Germany [6], Portugal and even in North America [64].

Habitat-Wastelands, open woods, riparian vegetation, hedges, roadsides in the thermo-Mediterranean zone, preferably on sandy and acid soils, up to $1100 \mathrm{~m}$ a.s.l. [8,18,65].

(9) Cirsium spathulatum (Moretti) Gaud., Fl. Helv. 5: 202. 1829 ECnicus spathulatus Moretti (basion.), Giorn. Fis. Ser. 2, 5: 111. $1822 \equiv$ Cirsium eriophorum subsp. spathulatum (Moretti) Ces. in Cattaneo Not. Nat. Civ. Lombardia 1: 302. 1844 ECirsium morettianum Nym., Syll. Fl. Eur.: 24. 185. 1854-1855, nom. illeg. (Art. 52.2) $\equiv$ Ci. eriophorum var. spathulatum (Moretti) Naeg., Syn. Fl. Germ. Helv. ed. 2 3: 989. $1845 \equiv$ Cn. eriophorus (L.) Roth subsp. spathulatus (Moretti) Arcang., Comp. Fl. Ital.: 404. 1882.-Neotype (designated here): Italy, "Comune nell'Italia settentrionale", s.d., [ante 1819], G. Moretti s.n. (G-DC00486193 [digital image!], sub Cn. ciliatus W.).-https:/ /www.ville-ge.ch/musinfo/ bd/cjb/chg/adetail.php?id=335721\&base=img\&lang=fr). - “Ci. insubricum Moretti ex Bertol.", Fl. Ital. [Bertoloni] 9(1): 25. 1853, nom. inval. (Art. 36.1b). 
Notes on Ci. spathulatum-The name was published after March 1822 ([66], p. 46). Moretti [67] wrote the following diagnosis: " $\mathrm{C}$ [nicus] foliis profunde pinnatifidis, laciniis bipartitis, lineari-lanceolatis, apice spinosis, margine ciliatis, subtus tomentosis. Calycibus nudis, squamis spathulatis, apice spinosis" (transl.: "A Cnicus with leaves deeply pinnatifid, with linear-lanceolate segments, in turn almost divided in two part, spiny at the apex, ciliate along the margin, tomentose below. With glabrous heads, involucral bracts spathulate, with spiny points"). The protologue also includes a description, a reference to Villars et al. ([68], p. 45) - who misapplied the name Ca. ciliatus Murr. to the same plant described by Moretti, the provenance ("in collibus ad meridiem Papiae"; transl.: "on the hills south of Pavia, northern Italy"), and a taxonomic note, all in Latin. Pertinent material is unfortunately lacking at BOLO, hosting specimens by Moretti (U. Mossetti, in litt.), or in other herbaria linked to Moretti [41]), i.e., C (O. Ryding, in litt.), FI (C. Nepi, in litt.), H (H. Väre, in litt.), PAD (R. Marcucci, in litt.), PAV (N.M.G. Ardenghi, in litt.) (no reply has been obtained by BASSA). A specimen at G (G00486193, http:/ /www.ville-ge.ch/musinfo/bd/cjb/chg/ adetail.php?id=335721\&base=img\&lang=fr) was sent by Moretti to Candolle in 1819 and was labelled by this latter author as "Cnicus ciliatus W.". It is difficult to employ as lectotype, because it lacks any obvious link to the protologue or any clear association with the epithet "spathulatus" (even if the spathulate bracts are described in a separate label by Candolle). However, at present, it could be a suitable choice as neotype, because it is directly linked to Moretti, matches the protologue, and shows the typical features of the taxon (namely, the shape of the bracts).

Notes on $\mathrm{Ci}$. morettianum-Nyman [69] proposed the name Ci. morettianum as a replacing name for the combination Ci. spathulatus, because, in his opinion, by this latter combination Gaudin [70] would indicate a different taxon as compared to that described by Moretti. However, as said above, on one hand $\mathrm{C}$. spathulatus is homotypic with $\mathrm{Cn}$. spathulatum; on the other hand, citing Ci. spathulatum, Nyman [69] published a superfluous and illegitimate name according to Art. 52.2, whose type is the type of Cn. spathulatum (Art. 7.5).

Note on Ci. insubricum-This name is reported by IPNI [27] as "Cirsium insubricum Moretti ex Bertol.". However, Bertoloni [45] (p. 25) listed it as an unpublished name occurring in Moretti's specimens, regarding it only as a synonym of Cn. eriophorus: it is invalidly published under Art. 36.1.

Taxonomy-The taxonomic value of this morph is controversial. Werner [5] recognized the specific rank, and Greuter [6] provisionally accepted it, while other authors (e.g., $[18,19,71])$ regard it as a subspecies of Ci. eriophorum. The morphological differences between $\mathrm{Ci}$. eriophorum and $\mathrm{C} i$. spathulatum (especially regarding the presence of spiny appendages on the middle bract and the indumentum of the heads) are slightly and variable. In addition, no ecological or geographical segregation of the two taxa has been observed. Further studies might to include Ci. spathulatum in the specific variability of Ci. eriophorum; or, on the contrary, to show a closer affinity with other European taxa, such as Ci. ligulare Boiss. or Ci. odontolepis Boiss. ex DC.: therefore, we provisionally accept the specific rank.

Distribution-Taxon endemic and very local to Northern Italy and Switzerland [6,19].

Habitat-Pastures, grasslands, wood margins and disturbed environments on mountains [71].

(10) Cirsium tenoreanum Petr., Sched. Cirsiotheca Univ. 17: n. 168. 1921, nom. nov. pro Ci. spurium (DC.) Lacaita, Nuovo Giorn. Bot. Ital. n.s. 25: 119. 1918, comb. illeg. (Art. 53.1), non Ci. spurium (Del.) Del., Ann. Sci. Nat., Bot. sér. 2, 18: 149. $1842 \equiv$ Ci. eriophorum var. spurium DC. (basion.), Prodr. 6: 638. 1838.-Lectotype (designated by Lacaita [46] (p. 121), as "autotipo"): Italy, Abruzzes [=Abruzzo], Collines autour du Lac Fucin, 1832, J. E. Duby s.n. (G00486363 [digital image!]).-http://www.ville-ge.ch/musinfo/bd/cjb/chg/ adetail.php?id=336417\&base=img\&lang=fr.

Notes on Ci. eriophorum var. spurium-Candolle [49] published the name of this new variety with a short diagnosis ("capitulis minoribus ovatis"; transl.: "with heads ovate and smaller [than in Ci. eriophorum]), relying on a specimen sent from Italy by Duby. The 
name was somewhat inspired by the Linnaean Ca. eriophorus var. spurius ([72], p. 824), indirectly cited by Candolle as a doubtful synonym by a reference to Linnaeus [73] ("An C. spurius Linn. hort. ups. 249?"), also cited by Linnaeus [72] himself in the protologue of Ca. eriophorus var. spurius. According to Del Guacchio and Iamonico [9], Ci. eriophorum var. spurium is to be regarded as the name of a new taxon, not having a basionym. On one hand, as those authors observed, the not validly published "Ca. spurius" (cited by Candolle) cannot be regarded as a basionym; on the other hand, however, it might be reasonable that the validly published Ca. eriophorus var. spurius is acceptable as basionym of the Candollean name under Art. 41.4. Actually, this article cannot be applied in any case, not even disregarding the taxonomic doubt by Candolle, because Ca. eriophorus var. spurius and $\mathrm{Ci}$. eriophorum var. spurium definitely refer to different taxa, i.e., Ci. $\times$ gerhardtii Schultz and Ci. tenoreanum respectively.

Notes on $\mathrm{Ci}$. tenoreanum-The epithet is dedicated to the famous Italian botanist Michele Tenore (1780-1861). As explained by Lacaita [74], by this name Petrak [75] intended to replace $C i$. spurium Lacaita, which had resulted a later homonym of Ci. spurium by Delastre [76] (p. 149) (cf. also Del Guachio and Iamonico [9]). The name by Petrak appeared for the first time in his series Cirsiotecha Universa, No. 168 in 1921; the same plant was also distributed later with number 198 (Scheuer [77]). According to Art. 30.8 (Ex. 12), the name was validly published in 1921. The printed label must be regarded as protologue, and the duplicates as obvious syntypes. The series is available in several herbaria: B, BM, C, G, K, LAU, PR, and W [57], and also M (http: / / indexs.botanischestaatssammlung.de/). We traced one duplicate of No. 168 in the personal herbarium of Lacaita himself, now kept at BM (BM001043049, http: / / data.nhm.ac.uk/dataset/collection-specimens/resource/ 05ff2255-c38a-40c9-b657-4ccb55ab2feb/record/1971813). The printed label reports the synonymy and the replaced name $\mathrm{Ci}$. spurium. The specimen (and possibly every duplicate of No. 198) originated by the personal collections of Lacaita, gathered in 1914 by Donato Profeta in Abruzzo [46] (p. 121). It fully supports the current usage of the name, attributed to a species endemic to central and southern Italy, where it is common [18]. Finally, the nomenclatural type of the name is the type of his replaced name, i.e., Ci. spurium, and therefore of the basionym of this latter, i.e., Ci. eriophorum var. spurium.

Distribution-Species endemic to the Italian peninsula, where it is common $[18,19]$.

Habitat-Pastures, grasslands, karst fields, paths, especially on limestones, from $1000 \mathrm{~m}$ to $1800 \mathrm{~m}$ a.s.l., rarely below [18] (pers. obs.).

(11) Cirsium vallis-demonii Lojac., Nat.. sicil. 3: 267. 1884 subsp. vallis-demonii $\equiv$ Ci. eriophorum var. vallis-demonii (Lojac.) Fior, Fl. Italia [Fiori, Béguinot and Paoletti] 3: 367. 1904 (sub "Vallis-Daemonii")._-Lectotype (designated by Aghababyan et al. ([55], p. 522)): Italy, Sicily, Valdémone [ . . . ] Mangalavite [ . . ] ], Julio 1882, M. Lojacono s.n. (G-BU).

=Cirsium eriophorum var. involucratum Coss., p. p. ([46], pp. 134-135).

— "Cirsium vallis-daemonis Lojac.", var. orth.—“Cirsium vallis-demonis Lojac.", var. orth.

(12) Cirsium vallis-demonii subsp. calabrum (Fiori) Del Guacchio, Bernardo, P.Caputo, Domina \& Iamonico comb. et stat. nov. $\equiv$ Ci. eriophorum var. vallis-demonii fo. calabrum Fiori, Fl. Italia [Fiori, Béguinot \& Paoletti] 3: 367. 1904.—Lectotype (designated here): Italy, Calabria, s.d., F.V. Zwierlein s.n. (FI, FI053596 (digital image!), sub Cirsium valdemonense Loj.)-Figure 4. 


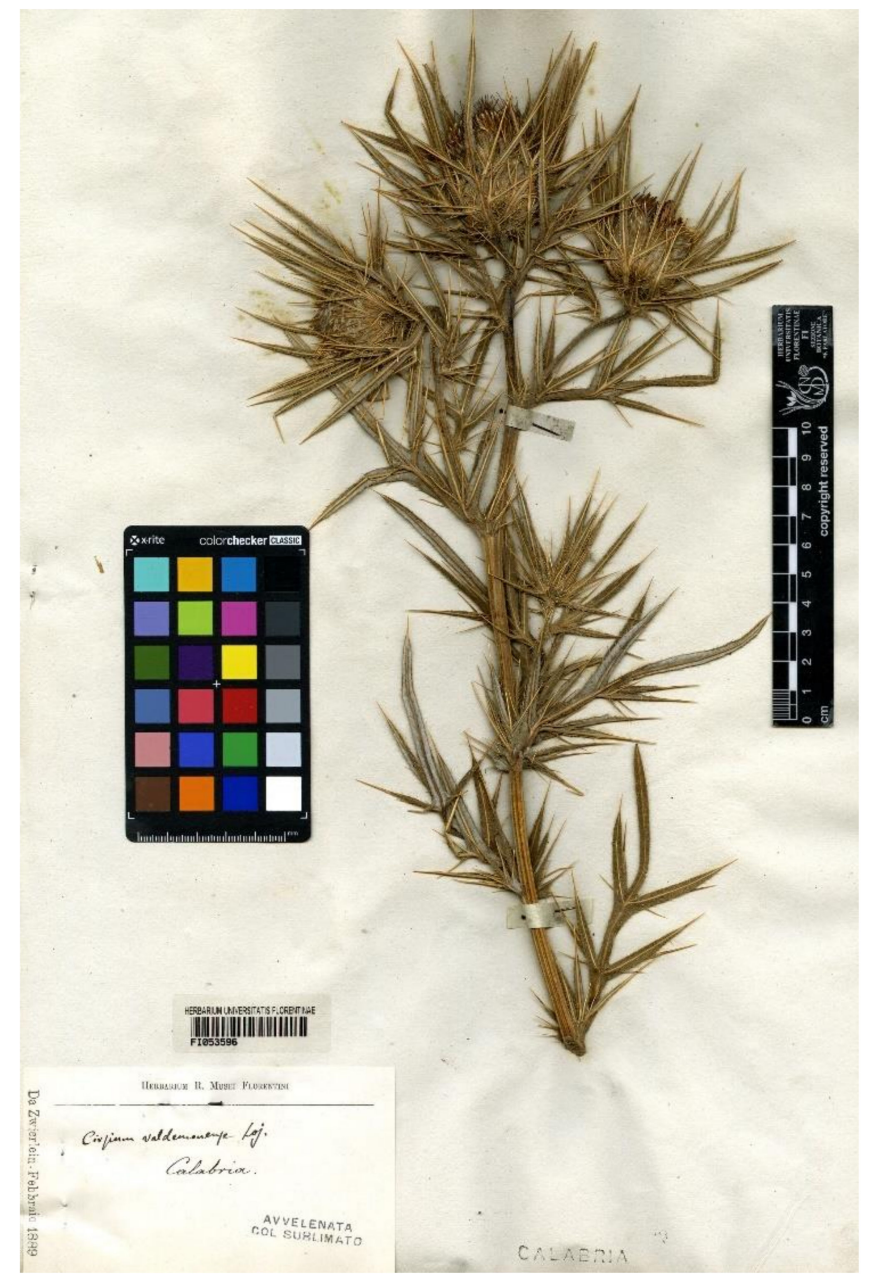

Figure 4. Lectotype of Ci. eriophorum var. vallis-demonii fo. calabrum Fiori (FI., barcode FI053596), by permission of the Curator.

Notes on Ci. eriophorum var. vallis-demonii fo. calabrum-Fiori [50] described this form with a diagnostic phrase in Italian: "Fi. rosso-porporini od anche (b. calabrum Nob. = Cirs. Vall.-Daem. var. Lojac.) bianchi" (transl.: "flowers red-purplish [in the typical variety] or white ([var.] b. calabrum Nob[is] = Ci. vallis-demonii var. [unnamed variety] Lojac."). Fiori [52] intended to validate at the form rank the taxon described by Lojacono Pojero [78]. This latter author, in fact, first observed that a specimen by F. V. Zwierlein from Calabria (Serra San Bruno) bore whitish or yellowish flowers. Nevertheless, his indications "Var. floribus albis" did not constitute a valid publication of a varietal name (Art. 23.6, Ex. 12). Therefore, according to Art. 9.4, we regard that specimen cited by Lojacono as original material for Fiori's name, because of the direct reference to Lojacono. However, original material collected by Zwierlein in Serra San Bruno and directly examined by Fiori before the publication of the protologue is preserved at FI, together with further material explicitly revised by Fiori but collected after the protologue. In particular, FI053595 and FI053596 (this latter mounted on two sheets) were sent by Zwierlein to Florence in 1882. FI053595 is represented by a flowering branch (only one head is visible) and bears a label partly printed ("Da Zwierlein-Febbraio 1889") and partly handwritten presumably by Zwierlein himself: "Cirsium valdemonense [sic!] Lojacono \in tutta la Sila ed a Serra San Bruno". FI053596 (first sheet) includes a flowering branch with three heads and a label identical to the other, but handwritten by Fiori: "Cirsium valdemonense Loj. \Calabria". The second sheet bears a further flowering branch, without label. The printed date on the sheet and the adoption of the epithet "valdemonense", not employed by Fiori later ([52,74,79] are convincing proofs that Fiori examined these specimens before the publication of the name. They show the 
typical features of $\mathrm{C}$. vallis-demonii (e.g., the medium-sized heads, the numerous involucral leaves surrounding and exceeding them, the erect outer involucral bracts); the colour is obviously not well observable in dried material, but it was undoubtedly withish in vivo (see the inner flowers of the central head in FI052596 \irst sheet). We choose FI053596 as the lectotype of the Fiori's name because it is more complete and bears the handwriting of the author.

Taxonomy - The Calabrian populations always show white-yellowish flowers [46] (L. Bernardo, pers. obs.); while in Sicily C. vallis-demonii has purplish flowers (G. Domina, pers. obs.). This character (i.e., purplish vs. whithish flowers) is taxonomical relevant, because - excluding obvious and sporadical albino individuals - it is constant within each species (cf. the dichotomous key in [3]). Besides, we found that at anthesis the middle involucral bracts are typically patent or divaricate in Sicilian populations, with purplish appendages; in the mainland populations only the inner bracts are divaricate, while the other ones are mostly erect or erect-patent, and the appendages are paler (E. Del Guacchio, pers. obs.). In addition, the leaves in var. calabrum would be typically less tomentose below [46], but this feature has been only partially verified by us on dried material (CAT, FI, PAL, PI). We note that, in the protologue, Fiori [52] reported the autonym form also for Calabria, but later he sharply kept the two ranges as distinct [79]. Also considering the complete separation of the ranges, we recognize the taxonomic value of fo. calabrum; nevertheless, following a more modern treatment, we prefer to propose here the subspecific rank for this taxon. The Strait of Messina and its adjacent mountains played an important role for subspecies differentiation: e.g., Adenostyles alpina (L.) Bluff \& Fingerh. subsp. nebrodensis (Wagenitz and I.Müll.) Greuter (endemic to Sicily) vs. subsp. macrocephala (Huter, Porta \& Rigo) Dillenb. and Kadereit (endemic to Calabria); Anthemis cretica L. subsp. messanensis (Brullo) Giardina \& Raimondo (endemic to Sicily) vs. subsp. calabrica (Arcang.) R.Fern. (endemic to Calabria); Aubrieta columnae Guss. subsp. sicula (Strobl) M.A. Koch, D.A. German and R. Karl (endemic to Sicily) vs. subsp. columnae (endemic to Italy, from Lazio to Calabria); Sesleria nitida Ten. subsp. sicula Brullo and Giusso (endemic to Sicily) vs. subsp. nitida (endemic to Italy, including Calabria); Thymus praecox Opiz subsp. parvulus (Lojac.) Bartolucci, Peruzzi and Passal. (endemic to Sicily) vs. subsp. polytrichus (A.Kern. ex Borbás) Jalas (southern Europe, including Calabria) [1,19]. Future studies with new morphological and molecular observations might enlighten further differences.

Distribution-Endemic to Italy: the autonym subspecies grows in northern Sicily (Peloritani, Nebrodi and Madonie massifs), while the subsp. calabrum occurs in Calabria (Sila, Serra San Bruno) [18]. The presence more northward is not confirmed; a presumed specimen of this species collected on Pollino massif (CAT-003141!) is rather to be referred to $C$. tenoreanum.

Habitat-Mountain pastures, grassy lake shores, open woods, on limestones or granitic soils, from about 800 to $1500 \mathrm{~m}$ a.s.l. [18] (pers. obs.).

(13) Cirsium vulgare (Savi) Ten., Fl. Napol. 5: 209. 1835-1836 三 Carduus vulgaris Savi (basion.), Fl. Pis. 2: 241. 1798, nom. nov. pro Ca. spinosissimus Gerbi, Storia Nat. Nuovo Insetto 8: 9. 1794, non Ca. spinosissimus Walter, Walter, Fl. Carol.: 194. 1788, non Ca. spinosissimus Villars, Hist. Pl. Dauphiné 3(1): 11. 1788.—Lectotype (designated here): [illustration] "Carduus spinosissimus" in Gerbi [80] (Figure 1).- https:/ / archive.org/ stream/bub_gb_s7upD7SkUP0C\#page/n11/mode/2up.

$=\quad$ Carduus lanceolatus L., Sp. Pl. 2: 821. $1753 \equiv$ Ascalea lanceolata (L.) Hill., Herb. Brit. 1: 72.1769 (cf. Art. 41.4) 三 Cirsium lanceolatum (L.) Scop., Fl. Carniol., ed. 2, 2: 130. 1772, nom. illeg., non Ci. lanceolatus Hill., Herb. Brit. 1: 80. 1769 (Arts. 52.1-52.2) $\equiv$ Cnicus lanceolatus (L.) Willd, Fl. Berol. Prodr.: 259. $1787 \equiv$ Eriolepis lanceolata (L.) Cassini in Cuvier Dict. Sci. Nat., ed. 2. [F. Cuvier] 41: 331. 1826.-Lectotype (designated by Talavera \& Valdés [25] (p. 197)): Herb. Linnaeus, No. 966.1 (LINN!). -http:/ /linnean-online.org/9800/.

= Cirsium rosani Ten., Index Sem. Hort. Bot. Neapol. 1830: 15.1830 (sub "Ci. rosani", cf. Art. 60.8 (a)) $\equiv$ Cnicus lanceolatum subsp. rosani (Ten.) Arcang., Comp. Fl. Ital.: 
403. $1882 \equiv$ Ci. lanceolatum subsp. rosani (Ten.) Arcang., Comp. Fl. Ital., ed. 2: 723. 1894.-Neotype (designated by Lacaita [46] (p. 125)): Italy, Basilicata, Potenza, s.d., F. Rosano? s.n. (NAP, collection Tenore!).-Figure 5.

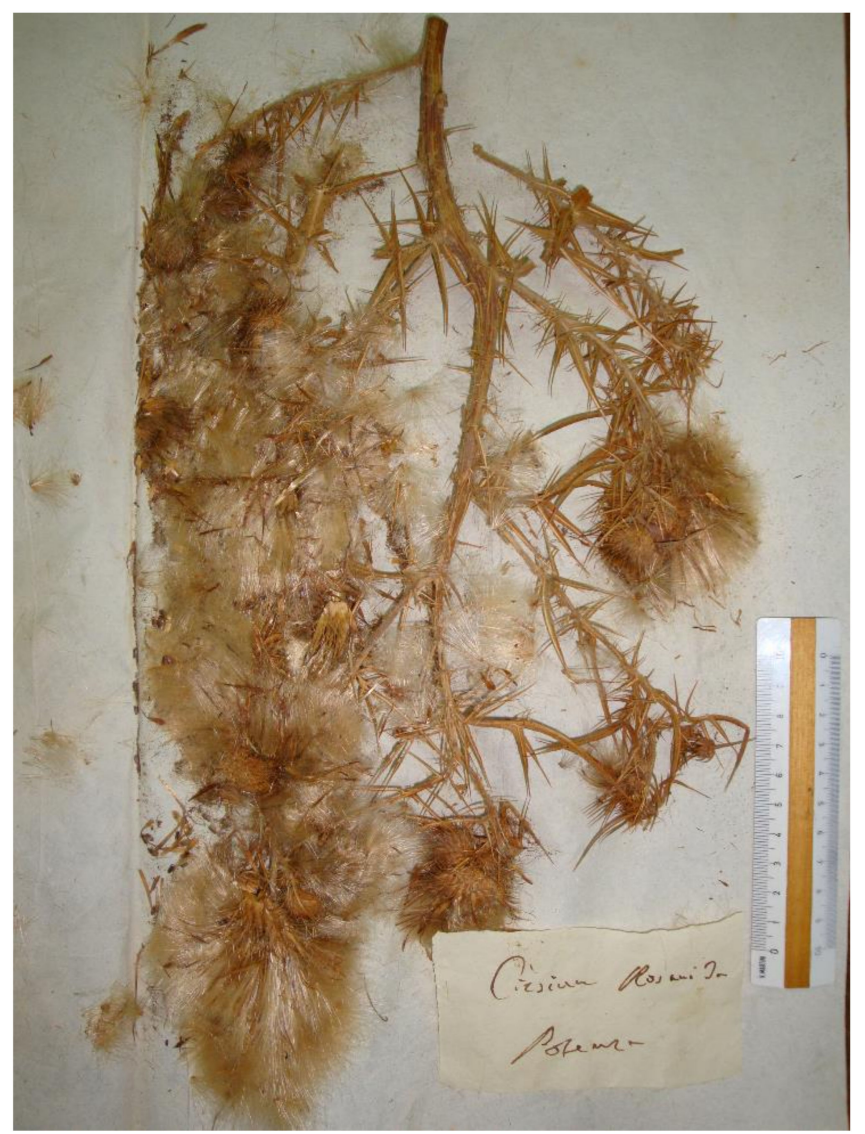

Figure 5. Neotype of $C n$. rosani Ten. (NAP), by permission of the Director.

$=\quad$ Cirsium crinitum Boiss. ex DC., Prodr. 7(1): $305.1838 \equiv$ Ci. lanceolatum subsp. crinitum (Boiss. ex DC.) Bonnier \& Layens, Tabl. Syn. Pl. Vasc. France: 175. 1894 (cf. p. VIII of the same work) $\equiv C i$. vulgare subsp. crinitum (Boiss. ex DC.) Arènes, Bull. Soc. Franç. Echange Pl. Vasc. 1: 21. 1948.- Lectotype (designated by Talavera \& Valdés [25] (p. 201)): France, Narbonne, 1828, E. Requien s.n. (G, G-DC00493688 [digital image!], sub Ci. echinatum).--http:/ / www.ville-ge.ch/musinfo/bd/cjb/chg/adetail.php? id $=407321 \&$ base $=$ img\&lang $=$ fr.

$=$ Cirsium misilmerense Ces, Pass. \& Gibelli, Comp. Fl. Ital. 2(21): 483. 1878.—Lectotype (designated here): Italy, Sicilia, Sotto Misilmeri, s.d. s.n. (RO!).-For an image of the lectotype, see Figure 6. 


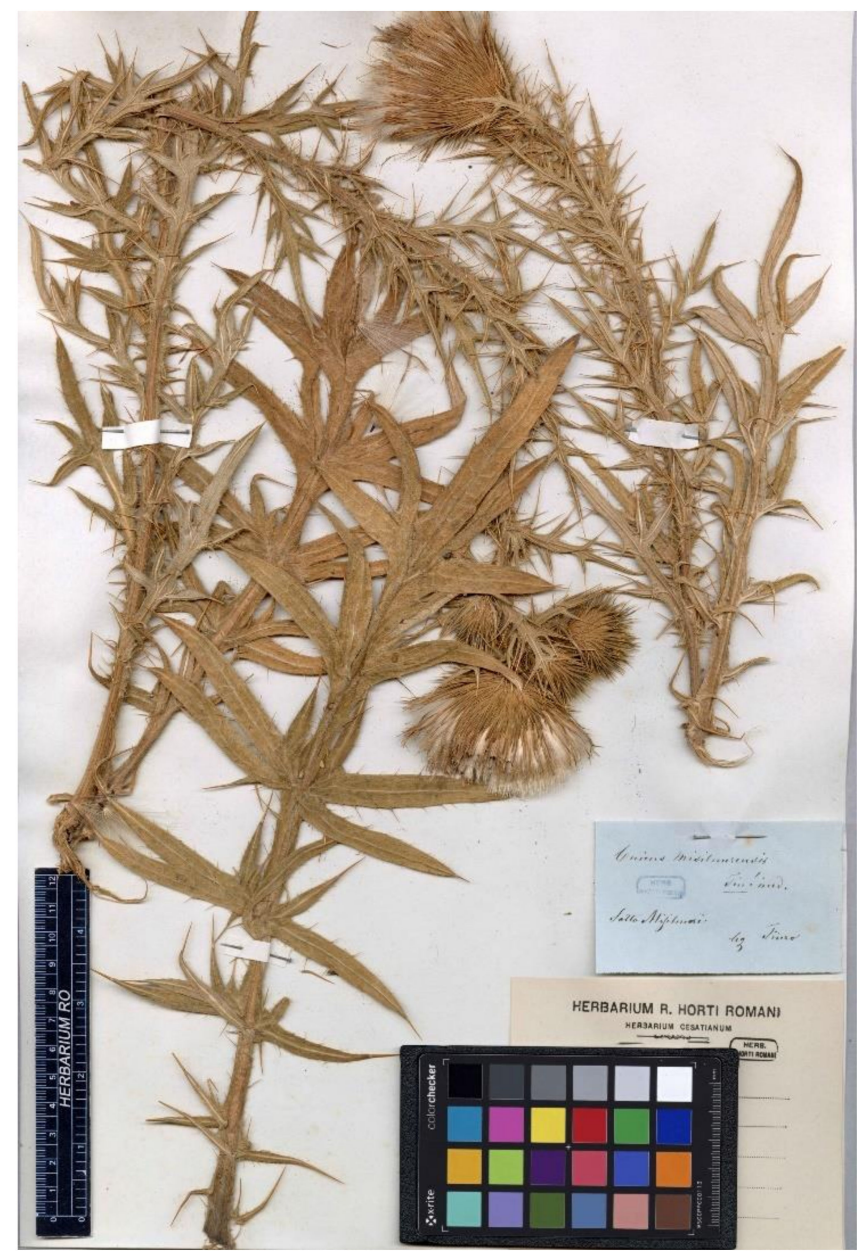

Figure 6. Lectotype of Ci. misilmerense Ces., Pass. \& Gibelli (RO), by permission of the Curator.

$=$ Cirsium cardoleonis Lojac., Fl. Sicul. 2(1): 158. 1903—Lectotype (designated by Aghababyan et al. [52] (p. 521)): Italy, Sicily, Santa Cristina, July 1873, M. Lojacono-Pojero s.n. (PAL, no. 10188!).—http:/ / 147.163.105.223/herbarium_vdetails_en2.asp?idmode=simple\&id= 22320.

$=\quad$ Cirsium dubium Lojac., Fl. Sicul. 2(1): 155. 1903.-Lectotype (designated by Aghababyan et al. [55] (p. 521)): Italy, Sicily, Regalbuto, s.d., Todaro s.n. (PAL, no. 10475!, sub Cn. lanceolatus var. incanescens).—http:/ /147.163.105.223/herbarium_vdetails_en2.asp? idmode $=$ simple\&id $=22476$.

$=$ Cirsium lanceolatum var. subbipinnatum Lojac., Fl. Sicul. 2(1): 155. 1903.-Lectotype (designated by Aghababyan et al. [55] (p. 522)): Italy, Sicily, Is. Eolie Alicuri, s.d., M. Lojacono (PAL, no. 10370!).—http:/ /147.163.105.223/herbarium_vdetails_en2.asp? idmode $=$ simple\&id $=22387$.

= Cirsium lanceolatum var. tenuispinum Lojac., Fl. Sicul. 2(1): 155. 1903 (sub "tenuispinus"). - Lectotype (designated by Aghababyan et al. [55] (p. 522)): Italy, Sicily, S Martino, s.d., M. Lojacono-Pojero s.n. (PAL, no. 10367!).—http://147.163.105.223/ herbarium_vdetails_en2.asp?idmode $=$ simple\&id $=22379$.

$=$ Cirsium vulgare var. longespinosum Rouy, Fl. France [Rouy \& Foucaud] 9: 21. 1905, nom. illeg. (Art. 52.1).-Lectotype (designated here): Italy, Sicily, Palermo sotto la Grazia, Aug [s.d., s.a.], A. Todaro n. 528 (PAL, no. 10364!, sub Ci. lanceolatum All. var. firmus).—http://147.163.105.223/herbarium_vdetails_en2.asp?idmode= simple\&id $=22375$.

$=\quad$ Ci. lucanicum Lojac., Nat. sicil. 3: 283. 1884-Type:-Not designated (see Domina et al. [81]). 
"Ci. lanceolatum var. vulgare Naeg.", Syn. Fl. Germ. Helv., ed. 2, 3: 990. 1845, nom. inval.

"Ci. vulgare (Savi) Airy-Shaw", Repert. Spec. Nov. Regni Veg. 43: 304. 1938, isonym (Art. 6, Note 2).

"Ci. vulgare (Savi) Petr.", Sched. Cirsiotheca Univ. 4: n. 33. 1912, nom. prov. (Art. 36.1). By this provisional name, Petrak indicated the taxon correctly named Ci. italicum [82].

Notes on Ca. spinosissimus-In a rare booklet, Gerbi ([80], p. 9-10) validly published the name Ca. spinosissimus. IPNI [27] reports on p. 9 as that of the protologue, but the plant was named and described in Italian already at p. 8, also providing a detailed description, and an illustration, i.e., "Figure I" by Gerbi [80], that is original material for the name. Unfortunately, the Gerbi name is a later homomyn of Ca. spinosissimus Walter, and so illegitimate under Art. 53.1. Since no specimens constituting original material were traced, we would designate the Gerbi's image as the lectotype of the name Ca. spinosissimus. The illustration depicts the plant nowadays called Ci. vulgare (Savi) Ten.

Notes on Ca. vulgaris-The name was published by Savi ([83], p. 241) after 22 January (D'Antroccoli and Peruzzi [84]) by a diagnosis ("Carduus foliis semi-decurrentibus, bifariam pinnatifidis, calycibus solitariis ovatis, sublanatis"; transl.: "A Carduus with leaves halfdecurrent, bi-pinnatifidous, with heads solitary, ovate, almost lanose") taken directly from the protologue of Ca. spinosissimus by Gerbi ([80], pp. 9-10). Moreover, Savi [83] explicitly wrote that he intended Ca. vulgaris as an avowed substitute (nomen novum) for the later homonym Ca. spinosissimus Gerbi. As a consequence, both Savi's name (Art. 7.4) and obviously its combination in Cirsium [85] (p. 209) are homotypic with it.

Notes on Ci. rosani-Contextually with the name Ci. lobelii, Tenore [48] (p. 14) published also a new species in Cirsium, dedicating it to his correspondent Francesco Antonio Rosano (1779-1843), who first gathered the plant in Basilicata (a region of southern Italy). The protologue includes a Latin description and the provenance ("In arvis Lucaniae prope Potentiam", i.e., "in the fields of Basilicata near the city of Potenza"). Also in this case, Lacaita [46] (p. 125) indicated an "autotipo" from Tenore's herbarium, a single specimen gathered in Potenza (Basilicata) by Rosano (Figure 5). Probably, it is original material; however, there is no definitive proof on the matter. Lacking certain original material, the designation by Lacaita must be retained. After the examination of the available material and the original description, and according to our broad circumscription of Ci. vulgare, Ci. rosani can be considered a heterotypic synonym. The plate in Flora napolitana [48], published slightly later than the protologue, supports this identification.

Notes on Ci. misilmerense-This name was published by Cesati et al. [86], who reported the diagnostic features of the taxon within a dichotomic key ("Brattee assai più brevi del capolino, squame dell'invoglio appressate e terminanti in uno spino diritto e pungente"; transl.: "Bracts much shorter than the capitulum, phyllaries appressed, each one with a terminal straight and stinging spine"), the indication of the locus classicus ("Sotto Misilmeri (Sicilia)"), and of the unpublished name "Cnicus misilmerensis Tineo! ined.". The exclamation mark infers that the new species was described on the basis of a specimen of Tineo's seen by Cesati. We found this specimen (original material) in the Herbarium Cesatianum at RO. It bears a well-preserved plant and the original label by Tineo "Cnicus misilmerensis Tin.! ined. I Sotto Misilmerilleg. Tineo". Another interesting specimen by Tineo is at PAL (no. 84936), but possibly it was not examined by the authors of the name. Even if regarded, especially in the past, as a distinct $[78,87,88]$ or a critical species [18,89], Ci. misilmerense is nowadays mostly included in the variability of Ci. vulgare subsp. crinitum $[6,19]$.

Notes on Ci. lucanicum-Lojacono Pojero [78] described this species on the basis of an apparently single exsiccatum collected by Gasparrini from Lucania (currently Basilicata region in southern Italy). In fact, as in the protologue, Lojacono Pojero [78] wrote "in specimine meo" ("in my specimen"), this could be interpreted as the only element on which he based the description; however, it is not considerable as the holotype [90]. Lojacono Pojero [78] did not ascribe the name to Gasparrini, but to himself: "Cirsium lucanicum 
MIHI. GASPARRINI ined. in Pl. sicc. ex Lucania". Unfortunately, we did not find any pertinent specimen at FI, NAP, MS, MPU, PAV, and PAL. The protologue includes a Latin description and an Italian diagnosis to distinguish Ci. lucanicum from Ci. italicum and Ci. lobelii sensu Lojacono (=C. tenoreanum). According to modern views [6,18], Ci. lucanicum is a synonym of $C i$. vulgare subsp. crinitum, which we include in Ci. vulgare. This statement is possibily based also on the taxonomic doubt expressed by Lojacono, who hypothesises that Ci. lucanicum could be Ci. rosani. Nevertheless, according to the protologue, Ci. lucanicum has not decurrent leaves, and this detail would definitely exclude the synonym. In absence of original material and considering this doubt about the synonymization, we refrain to typify this name at present.

Notes on Ci. vulgare var. longespinosum-Rouy [91] published this name citing Todaro's Flora Sicula Exsiccata n. 528, a synonym by Lamotte, a diagnosis in French (allowed at the time according to Art. 39.1), and some localities (at p. 22). Apparently, Rouy himself attributed the name to Todaro. However, as far as we known, this latter author never employed that epithet, not even in his exsiccata. M. Thiébaut (LY) (in litt.) informed us that Rouy [91] only cited Todaro's specimen but didn't hold it in his own herbarium. As Rouy [91] cited the previous and legitimate name Ci. lanceolatum var. horridulum Lam., whose epithet ought to have been adopted at varietal rank, its name is definitely superfluous and then illegitimate under Art. 52.1. Nevertheless, citing Flora Sicula Exsiccata n. 528, Rouy [91] actually indicated a type different from that of Lamotte, and we can treat it as the name of a new taxon (Art. 7.5, case b). On two specimens from Rouy's herbarium, originating from Basses Pyrénées and Aude-localitites reported in the protologue ([91], p. 22) -the author himself wrote by hand "longespinosum": LY0718280 and LY0718281. These specimens were collected before the protologue and are undoubtedly original material for the name. However, as a further consequence of citing Flora Sicula Exsiccata n. 528, the specimens of this series number are syntypes, which are preferred material for lectotypification (Art. 9.12), also those not seen by the author himself (Art. 9.4). Therefore, we would propose a pertinent specimen at PAL; other syntypes would be preserved in the herbarium cited by Stafleu and Cowan [92] (e.g., K000778051). The proposed lectotype was collected by Todaro near Palermo and is labelled as Ci. lanceolatum All. var. firmum" (see below for $\mathrm{Cn}$. firmus); it includes a flowering stem of $\mathrm{Ci}$. vulgare (stem completely winged, heads larger than $20 \mathrm{~mm}$ ).

Notes on Cnicus firmus-It is currently believed that the taxon named Cn. firmus C.Presl ([93], p. 107) is to be included in Ci. vulgare [6,18]. However, the examination of original material (PRC!) suggested that the taxon must be referred to another genus, and therefore that name is not treated here.

Taxonomy-This is a highly variable species. The infraspecific taxa recognized in modern times by several authors (e.g., [18,19]), i.e., C. vulgare subsp. crinitum (DC.) Arènes and C. vulgare subsp. silvaticum (Tausch) Arènes, are only preliminarily accepted by Greuter [6], Shin and Greuter [94] and are rejected by most scholars worldwide (e.g., $[1,5,8,42,84,95,96])$. According to the living or dried material examined by us and in the absence of any convincing discontinuity among the three presumed subspecies in terms of morphology, ecology or phytogeography, we agree with these authors.

Distribution-Widespread and common from the Mediterranean Basin and Europe to Asia, but naturalized worldwide [97,98].

Habitat-Clearings, riparian vegetation, hedges, fields, very often synanthropic (roadsides, ruderal environments, pathways, etc.), on rich and nitrified soils [97].

\section{Conclusions}

Nomenclatural studies play a central role in systematics and they should be regarded as essential and preliminary for any taxonomic assessment. On one hand, our contribution on Cirsium sect. Eriolepis in Italy allowed us to re-evaluate one neglected taxon (i.e., Cirsium vallis-demoniii f. calabrum) and to ascertain most synonymies for the correct interpretation of the names. On the other hand, we showed that, in some cases, previous synonymizations 
were erroneous (e.g., Cnicus firmus) or very doubtful. In addition, the examination of the original material of names linked to critical taxa (e.g., the three presumed subspecies of Cirsium vulgare) suggests that further research should be carried out before accepting taxonomic conclusions. Finally, some overlooked lectotypifications (e.g., C. morisianum) were brought to light.

Author Contributions: E.D.G. conceived the idea of the present manuscript and prepared the first draft of the paper together with D.I. F.C. provided additional bibliographic references. L.B. and G.D. checked the draft prepared by D.I. and E.D.G., suggested several improvements to the manuscript, and cured herbarium researches in CLU and PAL respectively. P.C. checked the draft prepared by D.I. and E.D.G., suggested several improvements to the manuscript, and cured the English language and the research in NAP. Duilio Iamonico searched the material for typification and prepared the first draft of the paper together with E.D.G. All authors have read and agreed to the published version of the manuscript.

Funding: This work was funded in part by the "Progetto di Ricerca di Rilevante Interesse Nazionale (PRIN) PLAN.T.S. 2.0-towards a renaissance of PLANt Taxonomy and Systematics" (grant number 2017JW4HZK).

Institutional Review Board Statement: Not applicable.

Informed Consent Statement: Not applicable.

Acknowledgments: We acknowledge directors and curators of all the herbaria mentioned above for their support during our visits or for loans of specimens/photographs. We thank L. Paino (Naples) for the useful information about the historical Library of the Botanical Garden of Naples, and Petr Bureš (Brno) for his precious suggestions.

Conflicts of Interest: The authors declare no conflict of interest.

\section{References}

1. POWO. Plants of the World Online. Facilitated by the Royal Botanic Gardens, Kew. Available online: http://www. plantsoftheworldonline.org/ (accessed on 8 December 2020).

2. Bureš, P.; Wang, Y.-F.; Horová, L.; Suda, J. Genome size variation in central European species of Cirsium (Compositae) and their natural hybrids. Ann. Bot. 2004, 94, 353-363. [CrossRef]

3. Keil, D.J.; Miller, C. Flora of North America North of Mexico; Flora of North America Editorial Committee, Ed.; Oxford University Press: New York, NY, USA; Oxford, UK, 2006; Volume 19, pp. 95-164.

4. APG [The Angiosperm Phylogeny Group]. An update of the Angiosperm Phylogeny Group classification for the orders and families of flowering plants: APG IV. Bot. J. Linn. Soc. 2016, 181, 1-20. [CrossRef]

5. Werner, K. Cirsium Mill. In Flora Europaea; Tutin, T.G., Heywood, V.H., Burges, N.A., Moore, D.M., Valentine, D.H., Walters, S.M., Webb, D.A., Eds.; Cambridge University Press: Cambridge, UK, 1976; Volume 4, pp. 232-241.

6. Greuter, W. Compositae (pro parte majore). In Euro+Med Plantbase-The Information Resource for Euro-Mediterranean Plant Diversity; Greuter, W., von Raab-Straube, E., Eds.; Available online: http:/ /ww2.bgbm.org/EuroPlusMed/ (accessed on 8 December 2020).

7. Carucci, F. Filogenesi Molecolare Del Genere Cirsium Mill. sect. Eriolepis (Cass.) Dumort. Ph.D. Thesis, University of Naples "Federico II", Naples, Italy, 2011.

8. Talavera, S. Cirsium Mill. In Flora Iberica; Devesa, J.A., Quintanar, A., García, M.Á., Eds.; Real Jardín Botánico Madrid (CSIC): Madrid, Spain, 2015; Volume 16, pp. 136-176.

9. Del Guacchio, E.; Iamonico, D. Typifications of the Linnaean names Carduus eriophorus, Carduus eriophorus var. spurius, and Cnicus ferox (Asteraceae). Phytotaxa 2015, 238, 196-200. [CrossRef]

10. Del Guacchio, E.; Caputo, P.; Iamonico, D. Typification of the name Cirsium lacaitae (Asteraceae). Phytotaxa 2019, 423, 273-276. [CrossRef]

11. Del Guacchio, E. Aquilegia vulgaris L. var. speluncarum Lacaita (Ranunculaceae): An enigmatic columbine from the Campanian Apennines (Southern Italy). Willdenowia 2009, 39, 63-68. [CrossRef]

12. De Castro, O.; Vallariello, R.; del Guacchio, E. Integration of morphology, genetics historical and ethnobotanical data: A case of an enigmatic Genista (Fabaceae) from Ischia Island (southern Italy). Phytotaxa 2013, 82, 64-68. [CrossRef]

13. Bartolucci, F.; Domina, G. Typification and taxonomic characterization of Thymus longicaulis C. Presl (Lamiaceae). Ann. Bot. Fennici 2014, 51, 54-62. [CrossRef]

14. Del Guacchio, E.; Gargiulo, R.; Caputo, P. Asperula calabra (Rubiaceae) and allied taxa in southern Apennines, Italy. Plant Biosyst. 2017, 151, 352-360. [CrossRef]

15. Iamonico, D.; Vallariello, R.; del Guacchio, E. Nomenclatural and distributional remarks on Limonium tenoreanum (Plumbaginaceae), a narrow endemic from southern Italy. Nord. J. Bot. 2017, 35, 445-448. [CrossRef] 
16. Erben, M.; del Guacchio, E.; Caputo, P. A nomenclatural study on Statice densiflora (Plumbaginaceae) and its linked names. Phytotaxa 2018, 369, 185-199. [CrossRef]

17. Del Guacchio, E.; Innangi, M.; Giacò, A.; Peruzzi, L.; Caputo, P. Taxa endemic to Campania (southern Italy): Nomenclatural and taxonomic notes. Phytotaxa 2020, 449, 217-231. [CrossRef]

18. Pignatti, S. Flora d'Italia; Edagricole: Bologna, Italy, 1982; Volume 3.

19. Bartolucci, F.; Peruzzi, L.; Galasso, G.; Albano, A.; Alessandrini, A.; Ardenghi, N.M.G.; Astuti, G.; Bacchetta, G.; Ballelli, S.; Banfi, E.; et al. An updated checklist of the vascular flora native to Italy. Plant Biosyst. 2018, 152, 179-303. [CrossRef]

20. Thiers, B. Index Herbariorum: A Global Directory of Public Herbaria and Associated Staff. New York Botanical Garden's Virtual Herbarium. Available online: http:/ / sweetgum.nybg.org/ih/ (accessed on 8 December 2020).

21. Turland, N.J.; Wiersema, J.H.; Barrie, F.R.; Greuter, W.; Hawksworth, D.L.; Herendeen, P.S.; Knapp, S.; Kusber, W.-H.; Li, D.-Z.; Marhold, K.; et al. (Eds.) International Code of Nomenclature for Algae, Fungi, and Plants (Shenzhen Code) Adopted by the Nineteenth International Botanical Congress Shenzhen, China, July 2017. Regnum Veg.; Koeltz Botanical Books: Glashütten, Germany, 2018; Volume 159. [CrossRef]

22. Gandoger, M. Flora Europae Terrarumque Adjacentium; F. Savy: Paris, France, 1887.

23. Gandoger, M. Novus Conspectus Florae Europeae; Weigel, T.O., Ed.; A. Hermann et Fil.: Paris, France; Leipzig, Germany, 1910.

24. Petrak, F. Der Formenkreis des Cirsium eriophorum (L.) Scop. in Europa. Biblioth. Bot. 1912, 18, 1-92.

25. Talavera, S.; Valdés, B. Revisión del género Cirsium (Compositae) en la Península Ibérica. Lagascalia 1976, 5, 127-223.

26. Pottier-Alapetite, G. Flore de la Tunisie; Ministère de l'Enseignement Supérieur et de la Recherche Scientifique et le Ministère de l'Agriculture: Tunis, Tunisia, 1979; Volume 2, p. 198.

27. IPNI. The International Plant Names Index. Available online: http://www.ipni.org (accessed on 8 December 2020).

28. Cuvier, F. (Ed.) Dictionnaire des Sciences Naturelles, 2nd ed.; F.G. Levrault $\backslash$ Le Normant: Strasbourg, France; Paris, France, 1827; Volume 50.

29. Naegelius, C. Dispositio specierum generis Cirsii. In Synopsis florae Germanicae et Helveticae, 2nd ed.; Koch, G.D.J., Ed.; Sumptibus Gebhardt et Reisland: Lipsia, Germany, 1845; Volume 3, pp. 987-1012.

30. Tofts, R. Cirsium eriophorum (L.) Scop. (Carduus eriophorus L.; Cnicus eriophorus (L.) Roth. J. Ecol. 1999, 87, 529-542. [CrossRef]

31. Daşkin, R.; Yilmaz, Ö.; Kaynak, G. Presence of Cirsium eriophorum (L.) Scop. (Asteraceae) in Turkey. Turk. J. Bot. 2006, 30, 461-465.

32. Bauhin, J.; Cherler, J.H. Historia Plantarum; Kessinger Publishing: Ebroduni, Switzerland, 1651; Volume 3.

33. De Lamarck, J.B. Flore Françoise; De L'Imprimerie Royale: Paris, France, 1779; Volume 2.

34. De Lamarck, J.B.; de Candolle, A.P. Flore Française, 3rd ed.; Agasse, H., Ed.; De L'Imprimerie Royale: Paris, France, 1805 ; Volume 4.

35. De Candolle, A.P. Catalogus Plantarum Horti Botanici Monspeliensis; Monspelii ex typis, J. Martel/apud A. Koenig: Montpellier/Paris, France, 1813.

36. Catalogue des herbiers de Genève (CHG). Conservatoire \& Jardin botaniques de la Ville de Genève. Available online: http: / / www.ville-ge.ch/musinfo/bd/cjb/chg/adetail.php?id=335990\&base=img\&lang=fr (accessed on 8 December 2020).

37. De L'Obel, M. Plantarum Seu Sitrpium Icons; Ex Officina Christophori Platini: Antwerp, Belgium, 1581; Volume 2.

38. Dodoens ["Dodonaeus"], R. Stirpium Historiae Pemptades Sex; Ex Officina Plantiniana: Antwerp, Belgium, 1616. [CrossRef]

39. Dalechamps, J. Historia Generalis Plantarum-Pars Altera; Apud Gulielmum Rovillium: Lugduni, The Netherlands, 1586.

40. De L'Obel, M. Icones Stirpium, 2nd ed.; Ex officina Plantiniana: Antwerp, Belgium, 1591; Volume 2.

41. Stafleu, F.A.; Cowan, R.S. Taxonomic Literature, 2nd ed.; Scheltema \& Holkema: Bohn, Germany; Utrecht, The Netherlands; Antwerp, Belgium, 1981; Volume 3.

42. Davis, P.H.; Parris, S.B. Cirsium Mill. In Flora of Turkey and the East Aegean Islands; Davis, P.H., Ed.; Edinburgh University Press: Edinburgh, UK, 1975; Volume 5, pp. 370-412.

43. Soldano, A. Nomenclatural notes on some Compositae of the Mediterranean Area. Compos. Newsl. 1992, 20-21, 4-11.

44. Tenore, M. Semina Anno MDCCCXXV Collecta, Quae Hortus Botanicus Neapolitanus Pro Mutua Commutatione Offert; Naturalis Biodiversity Center: Naples, Italy, 1825.

45. Bertoloni, A. Flora Italica; Ex typographaeo Haeredum Richardi Masii: Bologna, Italy, 1850; Volume 9, pp. 1853-1854.

46. Lacaita, C. Piante Italiane critiche o rare. N. Giorn. Bot. Ital. 1918, 25, 97-145, Plate II.

47. Del Guacchio, E. Note floristiche per la Campania. Delpinoa 2002, 44, 75-80.

48. Tenore, M. Semina Anno 1830 Collecta, Quae in Horto Botanico Neapolitano Pro Mutua Commutatione Offeruntur; Tipografia Fibreni: Naples, Italy, 1830.

49. De Candolle, A.P. ["1837"] Prodromus Systematis Naturalis Regni Vegetabilis; Sumptibus Sociorum Treuttel et Würtz: Paris, France, 1838; Volume 6. [CrossRef]

50. Rouy, G. Observations de M. Rouy sur le Cirsium eriophorum Scop. Bull. Soc. Bot. France 1904, 51, 427-428.

51. Dörfler, I. Herbarium normale. Schaedae ad Centuriam XXXI; E typographia “O. Hensel, Gottesberg”: Vienna, Austria, 1894.

52. Fiori, A. Compositae. In Flora Analitica d'Italia; Fiori, A., Paoletti, G., Eds.; Tipografia del Seminario: Padua, Italy, 1904; Volume 3, pp. 193-505.

53. Reichenbach, H.G. Icones Florae Germanicae et Helveticae; Sumptibus Ambrosi Abel: Leipzig, Germany, 1853; Volume 15, Plate 94.

54. Cupani, F. Panphyton Siculum; Antonino Epiro: Palermo, Italy, 1793.

55. Aghababyan, M.; Greuter, W.; Mazzola, P.; Raimondo, F.M. Typification of names of Compositae taxa described from Sicily by Michele Lojacono Pojero. Fl. Medit. 2008, 18, 513-528. 
56. Poiret, J.L.M. Voyage en Barbarie; J.B.F. Née de la Rochelle: Paris, France, 1789; Volume 2.

57. Stafleu, F.A.; Cowan, R.S. Taxonomic Literature, 2nd ed.; Scheltema \& Holkema: Bohn, Germany; Utrecht, The Netherlands; Antwerp, Belgium, 1983; Volume 4.

58. Da Ucria, B. Plantae ad Linneanum opus addendae, et secundum Linnaei systema noviter descriptae. N. Racc. Opusc. Aut. Sicil. 1793, 6, 245-256.

59. Costa, R.M.S.; Pavone, P.; Carbonaro, R.A.; Pulvirenti, S. Francesco Cupani's Panphyton Siculum. The rediscovery of a copy with handwritten corrections by his pupil Antonio Bonanno. Bot. Lett. 2016, 163, 203-216. [CrossRef]

60. Cupani, F. Hortus Catholicus; Franciscus Benzi: Naples, Italy, 1696.

61. Desfontaines, R. Flora Atlantica; Desgranges: Paris, France, 1799; Volume 2.

62. Todaro, A. Index Index Seminum Horti Regii Botanici Panormitani Anno MDCCCLVIII Quae Pro Mutua Commutatione Offeruntur; Horti regii botanici Panormitani: Palermo, Italy, 1859.

63. Sauter, A.E. Neue beiträge zur flora Deutschlands. Flora 1845, 28, 130-132.

64. Carapeto, A. New records of alien vascular plant species in mainland Portugal. Acta Bot. Malac. 2016, 41, 281-286. [CrossRef]

65. Talavera, S. Cirsium Miller. In Flora Vascular de Andalucía Occidental; Valdés, B., Talavera, S., Fernández-Galiano, E., Eds.; Ketres Editora S.A.: Barcelona, Spain, 1987; Volume 3, pp. 133-136.

66. Peruzzi, L.; Galasso, G.; Domina, G.; Bartolucci, F.; Santangelo, A.; Alessandrini, A.; Astuti, G.; D’Antraccoli, M.; Roma-Marzio, F.; Ardenghi, N.M.G.; et al. An inventory of the names of native, non-endemic vascular plants described from Italy, their loci classici and types. Phytotaxa 2019, 410, 1-215. [CrossRef]

67. Moretti, G. De quibusdam plantis Italiae. Decas tertia. Giorn. Fisica Chim. St. Nat. Med. Arti (Pavia) Ser. 2 1822, 5, $108-113$.

68. Villars, D.; Lauth, T.; Nestler, A. Précis d'un Voyage Botanique; Chez Lenormant: Paris, France, 1812.

69. Nyman, C.F. Sylloge Florae Europaeae; Sumptus et Typis, N.M. Lindh: Örebro, Sweden; pp. 1854-1855.

70. Gaudin, I. Flora Helvetica; Sumptibus Orellii, Fuesslini et Sociorum: Turici/Zürich, Switzerland, 1829 ; Volume 5.

71. Lauber, K.; Wagner, G.; Gygax, A. Flora Helvetica, 6th ed.; Haupt: Bern, Germany, 2018.

72. Linnaeus, C. Species Plantarum; Salvii, L., Ed.; Holmiae: Stockholm, Sweden, 1753; Volume 2.

73. Linnaeus, C. Hortus Upsaliensis; Laurentii Salvii: Stockholm, Sweden, 1748.

74. Fiori, A.; Béguinot, A. Schedae ad Floram Italicam Exsiccata; Tipografia Guerriera: Messina, Italy, 1923 ; Seria 3.

75. Petrak, F. Cirsiotheca Universa; Mährisch-Weißkirchen: Hranice, Czech Republic, 1921; Fasc. 17.

76. Delastre, M. Notices sur deux espéces des plantes, nouvelle pur la flora de la France. Ann. Sci. Nat. Botanique 1842, 18, 148-152. Available online: https://www.biodiversitylibrary.org/item/111688\#page/152/mode/1up (accessed on 8 December 2020).

77. Scheuer, C. Alphabetical Index to Dr. Franz Petrak's Exsiccata Series Cirsiotheca Universa; Institut für Botanik der Karl-FranzensUniversität: Graz, Austria, 2000.

78. Lojacono Pojero, M. Studi su piante critiche rare o nuove della flora di Sicilia (continua). Il. Nat. Sicil. 1884, 3, 266-269, $282-286$.

79. Fiori, A. (Ed.) Nuova Flora Analitica d'Italia; Ricci: Firenze, Italy, 1927; Volume 2.

80. Gerbi, R. Storia Naturale di un Nuovo Insetto [with one illustration "Figure I"]; Cambiagi: Florence, Italy, 1794.

81. Domina, G.; Greuter, W.; Mazzola, P.; Raimondo, F.M. Names of Italian vascular plants published by Michele Lojacono Pojero. Fl. Medit. 2014, 24, 215-232. [CrossRef]

82. Airy-Shaw, H.K. On the correct names of three European species of Cirsium. Feddes Repert. 1938, 43, 302-315.

83. Savi, G. Flora Pisana; Presso, P., Ed.; Giacomelli: Pisa, Italy, 1798; Volume 2. [CrossRef]

84. D'Antraccoli, M.; Peruzzi, L. Disentangling infraspecific taxonomy of Cirsium vulgare (Savi) Ten. (Asteraceae)-A first contribution from Tuscany. In Atti del 112 Congresso della Società Botanica Italiana; Siniscalco, C., Altamura, M.M., Biondi, S., Chiarucci, A., Cozzolino, S., Peruzzi, L., Poli, F., Sanitàdi Toppi, L., Eds.; Società Botanica Italiana: Parma, Italy, 2017; p. 95.

85. Tenore, M. Flora Napolitana; Stamperia e Cartiera del Fibreno: Naples, Italy, 1816; Volume 5, pp. $1835-1836$.

86. Cesati, V.; Passerini, G.; Gibelli, E.G. Compendio Della Flora Italiana; Francesco Vallardi: Milan, Italy, 1878 ; Volume 2.

87. Arcangeli, G. Compendio Della Flora Italiana, 2nd ed.; Ermanno Loescher: Turin, Italy, 1894.

88. Raimondo, F.M.; Bazan, G.; Troia, A. Taxa a rischio nella flora vascolare della Sicilia. Biogeographia 2011, 30, 229-239. [CrossRef]

89. Scoppola, A.; Caporali, C.; Gallozzi, M.R.; Blasi, C. Aggiornamento delle conoscenze floristiche a scala nazionale: Commenti e primi risultati. Inform. Bot. Ital. 2003, 35, 178-197.

90. McNeill, J. Holotype specimens and type citations: General issues. Taxon 2014, 63, 1112-1113. [CrossRef]

91. Rouy, G. Flore de France; Imprimeire Deslis Fréres: Tours, France, 1905; Volume 9.

92. Stafleu, F.A.; Cowan, R.S. Taxonomic Literature, 2nd ed.; Scheltema \& Holkema: Utrecht, The Netherlands; Antwerp, Belgium, 1986; Volume 6. [CrossRef]

93. Presl, J.S.; Presl, C.B. Deliciae Pragenses; Sumtibus Calvae: Prague, Czech Republic, 1822; Volume 1.

94. Shin, Z.; Greuter, W. Cirsium Miller. In Flora of China; Wu, Z.Y., Raven, P.H., Hong, D.Y., Eds.; Science Press: Beijing, China; Missouri Botanical Garden Press: St. Louis, MO, USA, 2011; Volumes 20-21, pp. 160-175.

95. Charadze, A.L. Cirsium Mill. emend. Scop. In Flora of the USSR; Bobrov, E.G., Czerepanov, S.K., Eds.; Editio Academiae Scientiarum URSS: Moskow/Saint Petersburg, Russia, 1963; Volume 28, pp. 51-215.

96. APD [African Plant Database]. Version 3.4.0; Conservatoire et Jardin botaniques de la Ville de Genève and South African National Biodiversity Institute: Pretoria, South Africa; Available online: http://www.ville-ge.ch/musinfo/bd/cjb/africa/ (accessed on 8 December 2020). 
97. CABI. Cirsium Vulgare; CAB International, Ed.; Invasive Species Compendium: Wallingford, UK; Available online: www.cabi.org/ isc (accessed on 8 December 2020).

98. USDA. Germplasm Resources Information Network (GRIN-Taxonomy); Beltsville (Maryland); National Germplasm Resources Laboratory: Beltsville, MA, USA. Available online: https://npgsweb.ars-grin.gov/gringlobal/taxonomydetail.aspx?id=104163 (accessed on 8 December 2020). 